

\section{0 \\ (773) 4 v.}

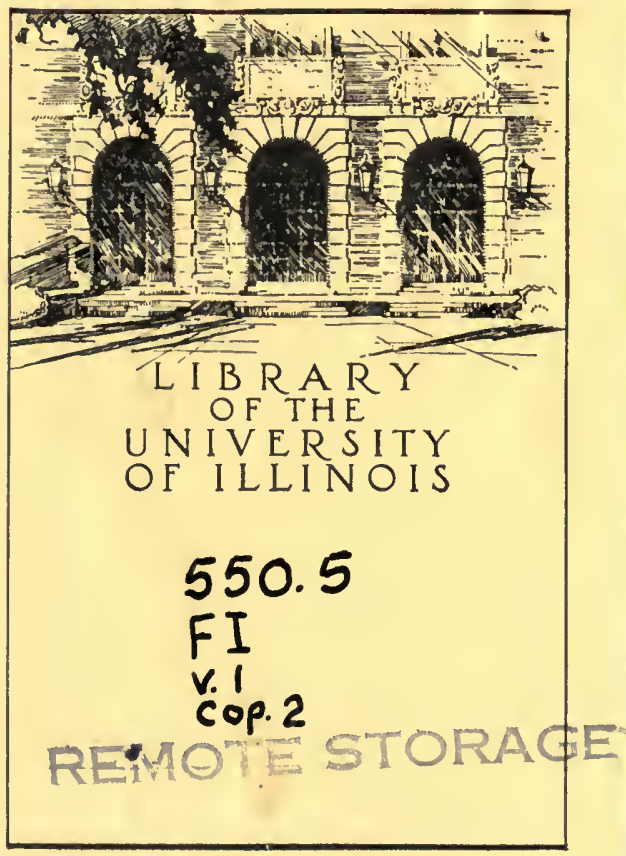





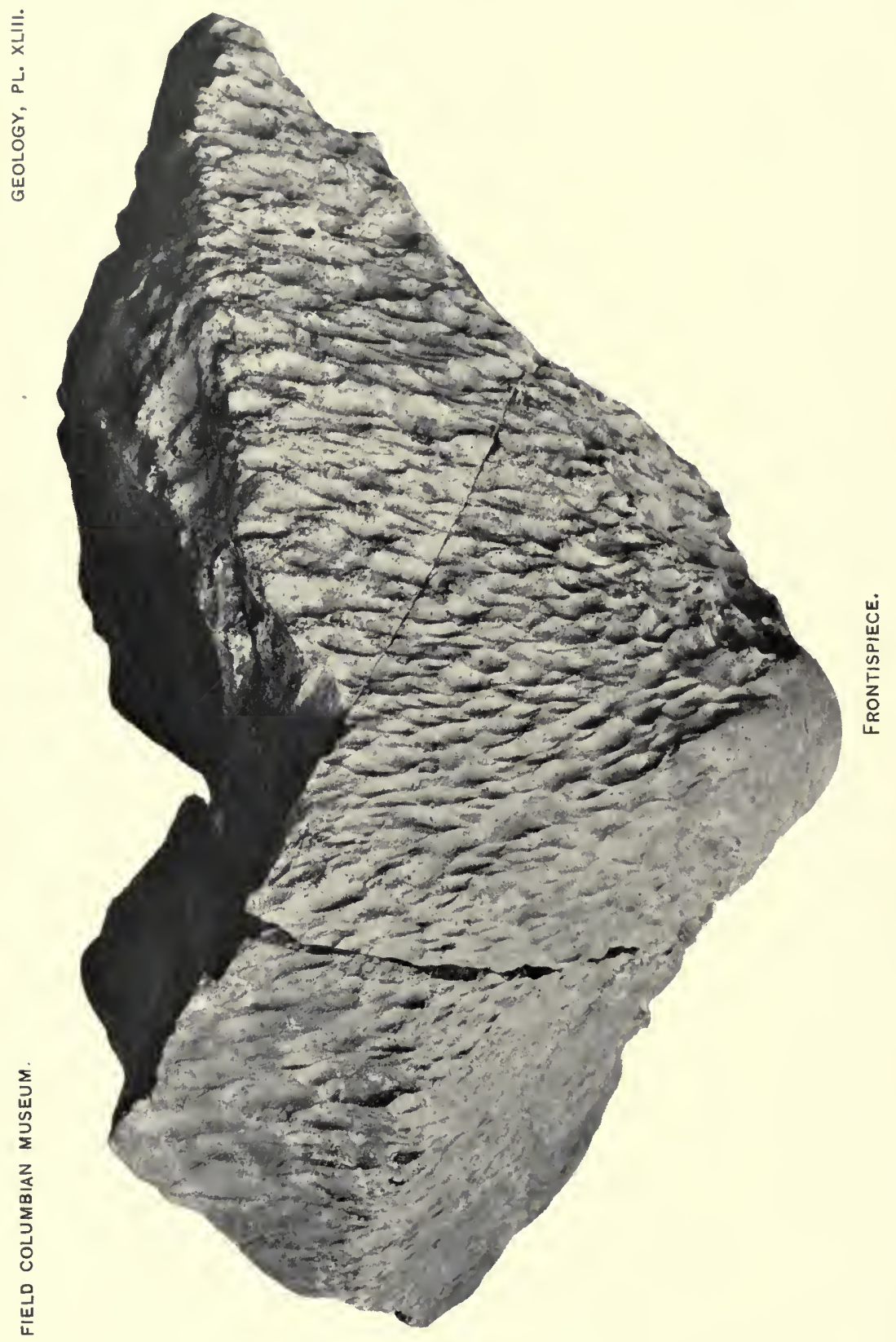




\section{MIPEOHITE SHUIRIES- I}

\section{explanation of plate XliII.}

Long Island meteorite as at present restored. $\times \frac{1}{6}$.

From a photograph. The position from left to right of the page is that probably assumed by the meteorite in falling. 



\section{Field Columbian Museum}

\section{Publication 64.}

Geological Series.

VOL. I, Nu. II.

\section{METEORITE STUDIES-I.}

BY

Oliver Cummings Farrington, Ph. D.

Curator, Department of Geology.

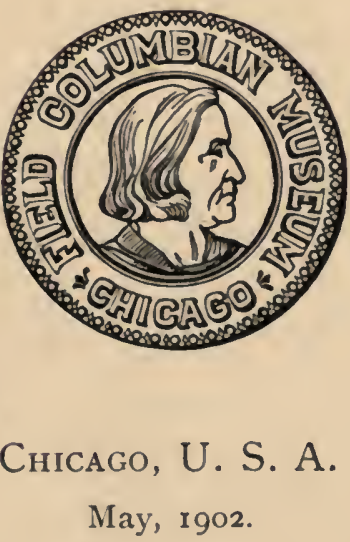





\title{
METEORITE STUDIES-I.
}

\author{
By Oliver Cummings Farrington.
}

\section{LONG ISLAND, PHILLIPS COUNTY, KANSAS. MUSEUM NUMBER Me. 420.}

Nearly all of this great meteorite is possessed by the Museum and this has been the case since the opening of the institution in June, I 894, but it has never been fully described. A few lines were devoted to the meteorite and a cut of it shown in the catalogue of the meteorite collection published in August, $1895 .^{*}$ A petrographic description from fragments of the stone was also given by E. Weinschenk in $1895 . \dagger$

No account of the finding of the stone seems ever to have been published however and there are many other features which are well worthy of description. For details regarding the occurrence of the stone I am indebted to Prof. Williston of the University of Kansas and Prof. Willard of the Kansas Agricultural College. Prof. Williston states that a fragment of the meteorite first reached him in the fall of 1892 . Prof. Willard secured one at about the same time. On recognizing the meteoritic nature of the fragments sent them, Profs. Williston and Willard at once entered upon negotiations for the purchase of the mass and soon became its possessors. The work of collecting the pieces at the original locality was done by Prof. Willard, and to him I am indebted for information regarding the occurrence there.

The meteorite lay, he states, on a slope of the ordinary soil of the upland prairie region. There is no outcrop of rock in the immediate vicinity and none within several miles, so far as he knows. Where there is an outcrop the rock is limestone. The distribution of the pieces of the meteorite as first seen by Prof. Willard was such as to indicate that the mass had struck upon the slope and its front portion being stopped, the rear portion had broken up and gone ahead. The four large pieces which are put together to make the mass shown in

* Field Columbian Museum Publication 3, p. 59.

$\dagger$ Tsch. Min. u. Petr. Mitth., Vol, 14, p. $\$ 71$. 
Plate XLIII (Frontispiece) were together and in contact at the upper end of the fall. The top of these projected about four inches above the soil and the lowest point to which they reached was perhaps two feet below the surface. Beside these large pieces a quantity of smaller fragments more or less imbedded in the ground extended down the slope in a northwest direction for a distance of from 15 to 20 feet in a gourd-shaped area which was perhaps six feet wide at the widest point. The accompanying section and plan (Fig. I) from a sketch by Prof. Willard will give an approximate idea of the manner in which the fragments lay. The location of the spot where the meteorite was found is about three miles west of the present town of Long Island,

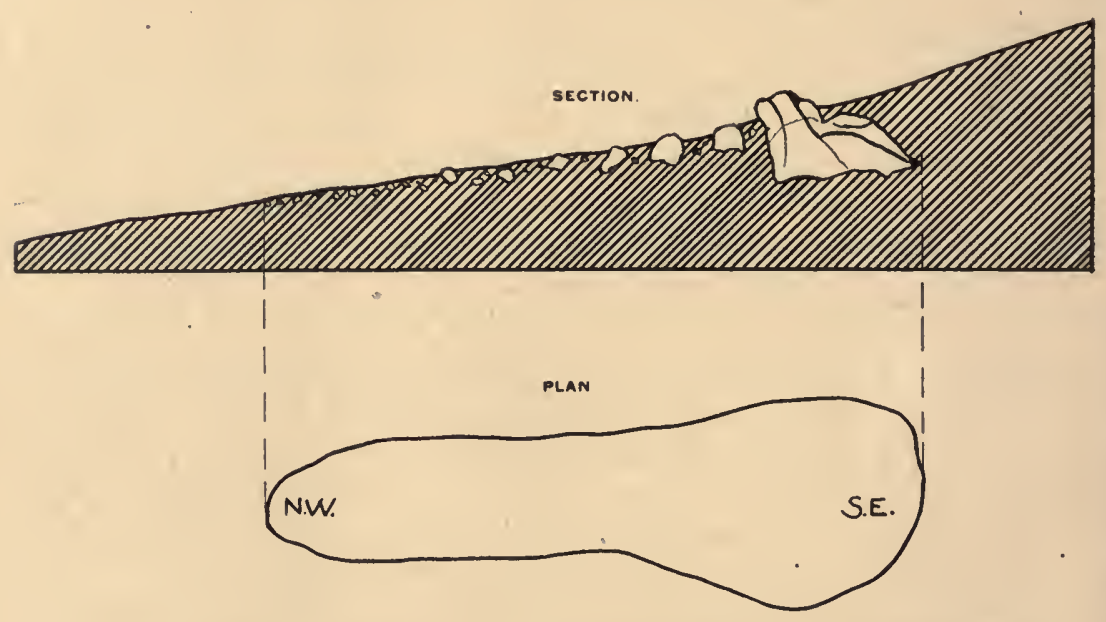

FiG. I. Section and plan showing nature of occurrence in place of the Long Island meteorite.

one-half mile east of the west line of Phillips County and three miles south of the Kansas-Nebraska State line. It is from the neighboring town of Long Island that the meteorite takes its name. With regard to the time of the fall no knowledge has yet been obtained. The stone was noticed by early comers to the region and was generally reputed to be a meteorite, so that visitors had in many cases taken away pieces as curiosities. That the mass had lain a number of years in place is proved by the coating of carbonate of lime, in some places two or three millimeters in thickness, which encrusts many of the pieces. Further evidence of the long exposure of the stone is given by the weathered character and rusty brown color of the surface of exposed fragments of the stone in contrast to the dark green color of their interior. The meteorite as collected by Prof. Willard was 
shortly afterward purchased by Mr. George F. Kunz, of New York City, and after remaining in his possession for about a year was secured for this Museum.

The entire weight of the meteorite as received at the Museum and made up of 4 large and 2,930 small fragments, was I, I 84 pounds (537 kilos). This was supposed at the time to be the entire weight of the mass, but a year or two later Mr. Kunz obtained about 60 pounds (27 kilos) more, which is for the most part still in his possession. This additional material was chiefly fragments obtained from people in the region who had carried off portions of the stone for curiosities. A weight of at least 1,244 pounds $\left(56_{4}\right.$ kilos) can therefore be positively assigned the stone and there is little doubt that it originally weighed somewhat more than this since some pieces were probably carried off that will never be recovered. That the fragments all belonged to a single mass the manner of their occurrence in place leaves no doubt. Moreover their edges show no rounding or fusing as would have been the case had any of them made an independent passage through any considerable part of the earth's atmosphere. The stone is therefore much the largest single stone meteorite known to exist, its nearest competitors being the Bjurbole meteorite, which weighs 748 pounds ( 340 kilos) and one of the stones of the Knyahinya fall, which weighs 649 pounds (295 kilos).

As soon as the installation of the stone was,undertaken at the Museum, it was at once seen that the four large pieces fitted together. When this was done the form shown in Plate XLIII (Frontispiece) was produced. Doubtless others of the fragments could be added to these, but as an effort to do this proved on trial to be likely to consume considerable time without giving any important results, the attempt was abandoned. There would be more hope of success if the Museum possessed the entire mass of the stone, but as it is, many of the fragments would be missing at best. The four large pieces weigh together 669 pounds ( 303 kilos), or more than half the weight of the stone. They hence probably give its essential form. Their weights are $269,239,891 / 2$ and $711 / 2$ pounds ( $122,108,46$ and 32 kilos) respectively. The largest of the remaining fragments at the Museum weighs $22 \mathrm{r} / 4$ pounds (ro kilos), which is a weight much below that of the smallest of the four large ones. Mr. Kunz informs me that one of the fragments in his possession weighs about 35 pounds (I 5.8 kilos). The smaller fragments range from the weight above mentioned to those not over a gram in weight. Some have the true meteorite crust on one surface, showing that they are from the superficial portion of the stone, while the rough, irregular surfaces of the remaining frag- 
ments show that they were wholly within the interior. The portion of the stone to which these fragments would be attached if a complete restoration of its form could be made would be that to the rear and to the left of the part shown in Plate XLIII (Frontispiece) or to the rear of the stone in the position in which it is shown in Fig. I, Plate XLIV. As will be seen by referring to Plate XLIII (Frontispiece) the portion of the stone to the right of a vertical line drawn through the middle of the plate has an almost wholly natural surface. Over this portion therefore the actual form of the stone is preserved. The form of the stone as at present restored is, as shown by the plate, roughly that of a low cone. The greatest diameter of the base of the cone is 34 inches $(86 \mathrm{~cm}$.) and the altitude from base to apex 20 inches $(51 \mathrm{~cm}$.). The conical form, as is well known, is the typical one to which meteorites are reduced in their passage through the atmosphere, from the fact that the portion of the mass in front receiving the brunt of the friction and heat is worn down rapidly to an apex from which the other portions slope away. That this is the position which the Long Island stone took in falling is further indicated by the smooth, unpitted character of the base of the cone (Rückseite) as compared with the pitted surface of the conical portion, and further by the fact that the series of pittings (piezoglypten) on the surface extend in radial directions from the apex of the cone. It will be noted in the plate that the long axes of the pits run in directions nearly parallel to lines drawn from the apex to the base of the cone. These then were the directions of the air currents. The planes along which the four large fragments were separated and along which they have now been joined together are not courses of ordinary irregular fracture, but are definite divisive planes. There are three of these planes, two being continuous each in its own direction while the third may be described as made up of two planes meeting at a very broad angle $\left(160^{\circ}\right)$. The planes run in three directions nearly at right angles to each other. They meet, but only at one point do they pass through one another. If one will conceive of an apple cut in halves by a plane starting a little to one side of the bloom, one of these halves then cut through equatorially in a direction at right angles to the first plane by two planes starting a little above the equator, but meeting at it, then the quarter nearest the bloom cut through by a plane at right angles to the equatorial plane in a direction running from the bloom to the stem, and passing into the otherwise uncut half for quite a distance, an idea will be gained of the course of the division planes of this meteorite. Their course can also be seen by reference to Plate XLIV. 
The area of each plane is approximately as follows:

Plane $A=200$ sq. in. ( $13 \mathrm{sq}$. dm.)

Plane $B=I 96$ sq. in. ( 12 sq. dm.)

Plane $\mathrm{C}=\mathrm{I}$ I 3 sq. in. (7. I sq. dm.)

The position of these planes makes it unlikely that they were developed by the blow of the meteorite in striking the earth, for one at least runs nearly at right angles to the probable direction of

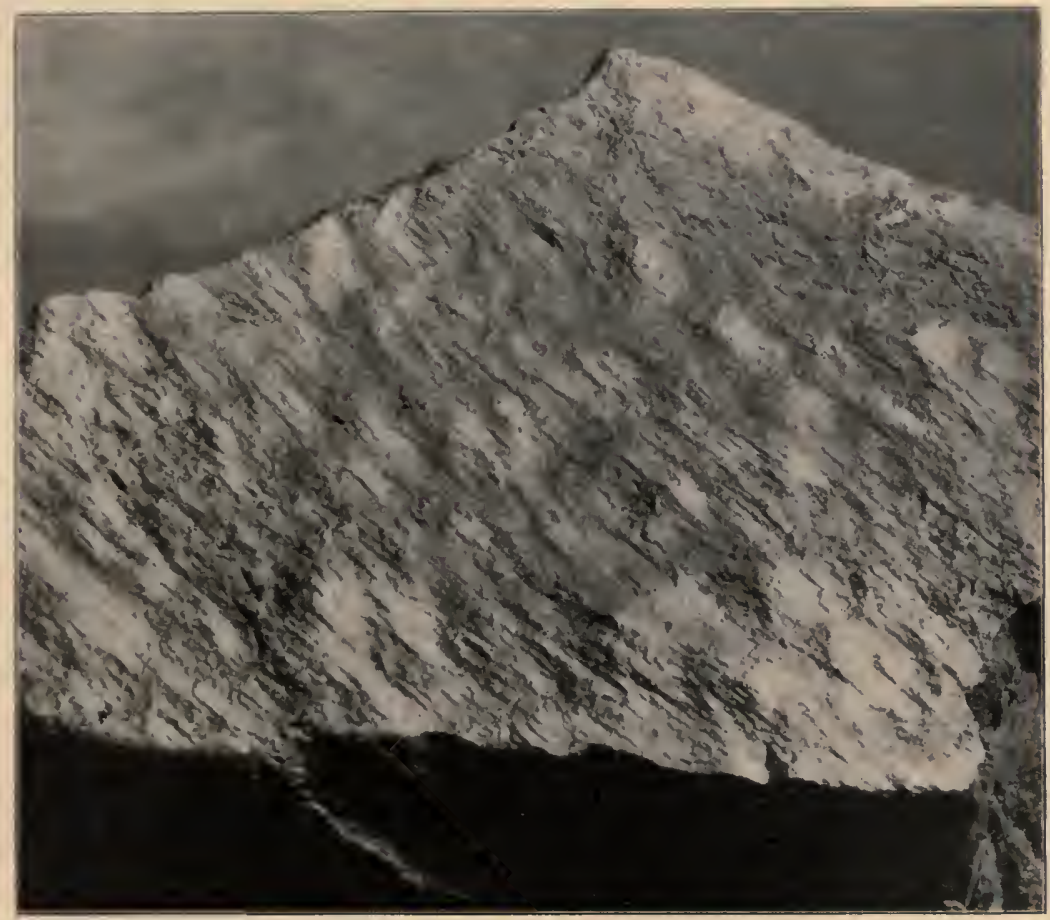

F1G. 2. Slickensided surface of Long Island meteorite. $\times \mathbf{x}$.

motion of the meteorite. Further, as stated more in detail below, the striæ of the slickensided surfaces run in different directions.

The plane marked (A) in Fig. 2, Plate XLIV, runs quite nearly in the direction of probable motion and it is interesting to note that near each end of the meteorite irregular cracks appear which are approximately parallel to this plane. Their position suggests that they may have been produced by the tendency of the base of the meteorite to continue its motion after the apex had been stopped by striking the earth. The plane marked (C) separating Pieces 2 and 4 can be noted continuing on in Piece I as a line which extends nearly 
to the edge of that piece. This portion of the plane evidently was not sufficiently developed as a division plane to produce disruption of the piece when the meteorite struck the earth.

That the three planes described represent a structure which existed in the meteorite before its entry into the earth's atmosphere there can be little doubt. They are too regular to make it possible to consider them planes arising from fracture by shock and there are several other lines of evidence pointing to their preterrestrial existence. The most important of these is that their surfaces are slickensided. The slickensided character of the surface resembles that seen in terrestrial rocks and is illustrated in Fig. 2. It is a smooth, shining, somewhat undulatory, like a roche moutonnée surface, and bears short striæ which on the same surface run in one general direction, but take different directions on the three several planes. These several directions are indicated in Plate XLIV, Fig. 2, where one of the fragments is represented as removed. The color of the slickensided surfaces is somewhat darker than that of the crust of the meteorite, but there is no evidence of special heat having been developed by the force which produced the slickensides. This I have tested by cutting sections at right angles to the surfaces. The outlines of the individual grains were found to be sharp and unaltered up to the slickensided edge.

Since slickensided surfaces on terrestrial rocks are so far as known produced by slow differential movement in the mass under considerable pressure and while in the solid state, they may in the absence of any evidence to the contrary be assigned to the same cause in this meteorite. The conclusion seems fair therefore that these planes and surfaces were formed during the preterrestrial existence of the mass and that the mass must. have been solid in its nature while in space. The three planes which I have described seem to me to resemble the joint planes of terrestrial rocks more than anything else I can think of and give us grounds for asserting the existence of joint structure in the rocks of space. I do not know that well marked joint structure has been observed in any other meteorites except that noted by Meunier in one of the stones of L'Aigle*. This stone he regarded as possessing a joint fissure, but it was not as well developed as the planes of the Long Island stone.

If the occurrence of joint structure in the Long Island stone is deemed proved, it is significant as pointing to a considerable mass possessed by the body in space. Joint blocks of such size as this would not be likely to be developed in a small body. 


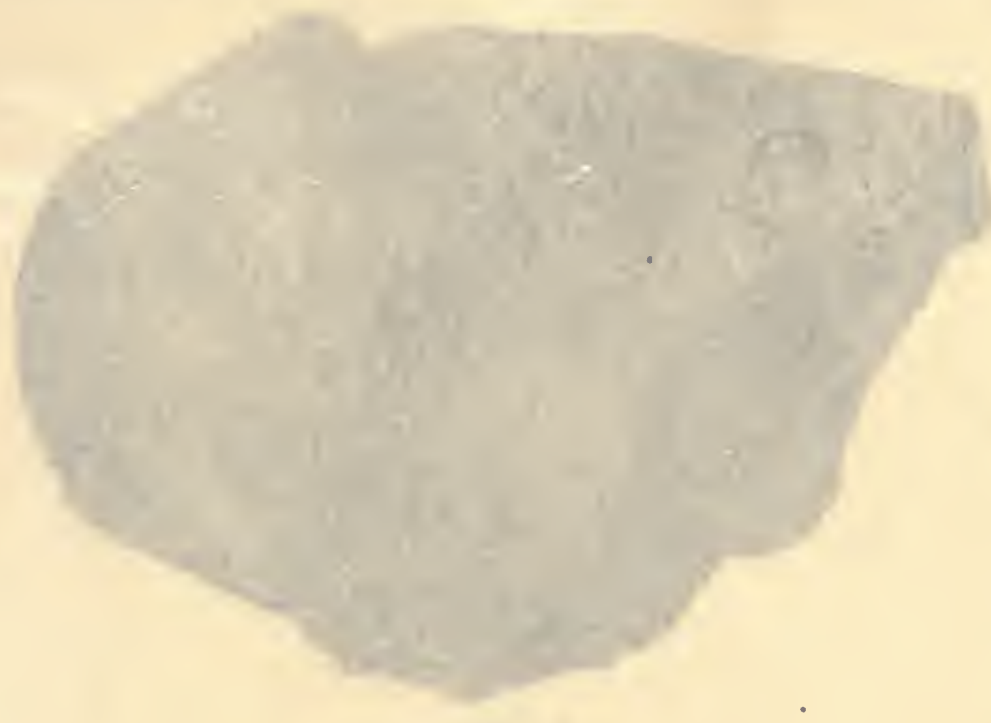

. VI 3 X $3 T_{\text {A.J }} 9$ 70 HOITAMAJ9X3

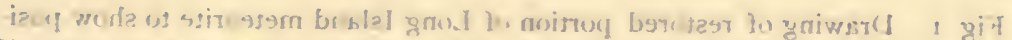

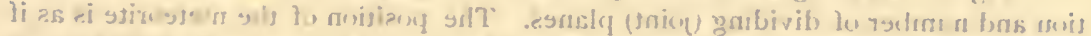

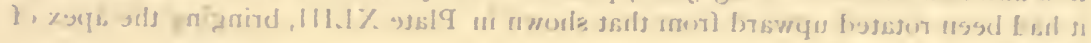

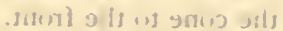

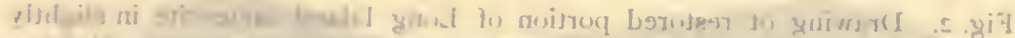

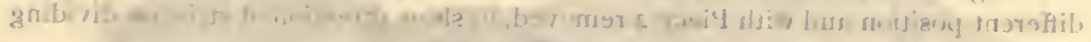
yonsla esriug) 


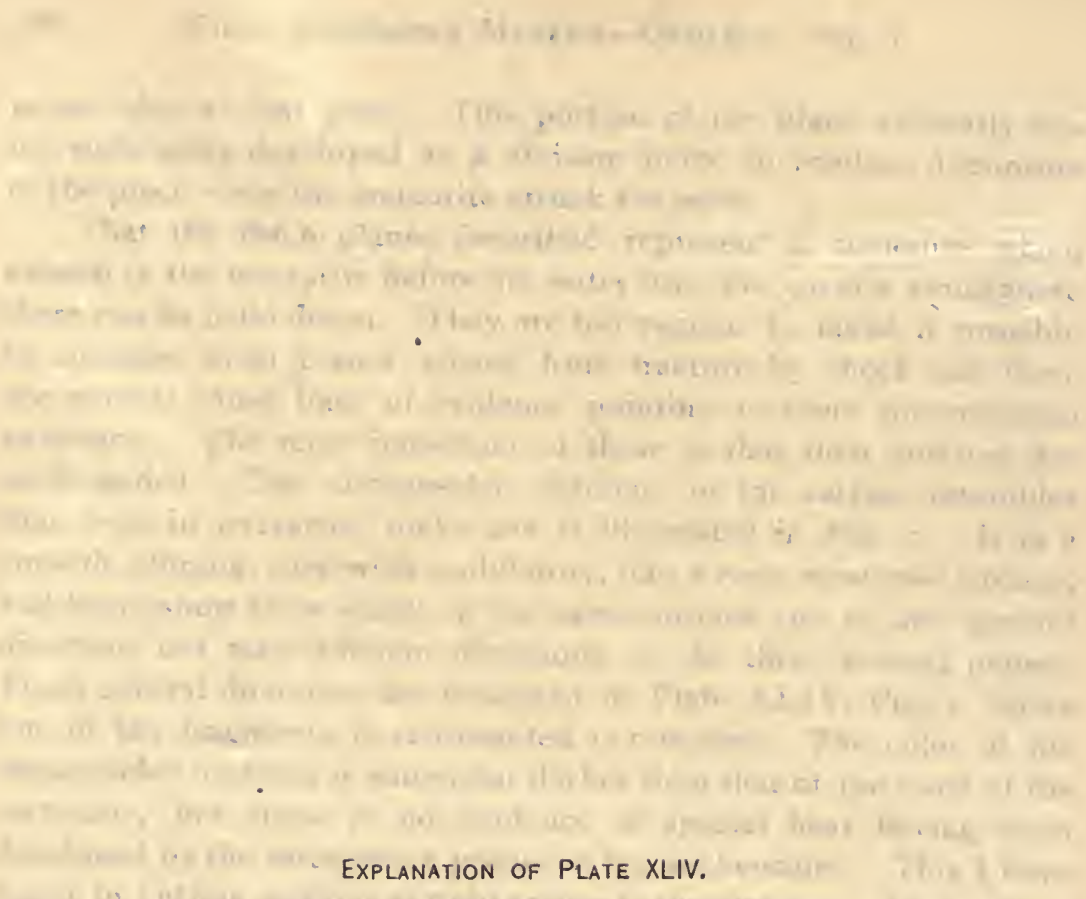

Explanation of Plate XLIV.

Fig. I. Drawing of restored portion of Long Island meteorite to show position and number of dividing (joint) planes. The position of the meteorite is as if it had been rotated upward from that shown in Plate XLIII, bringing the apex of the cone to the front.

Fig. 2. Drawing of restored portion of Long Island meteorite in slightly different position and with Piece 2 removed, to show direction of striæ on dividing (joint) planes. 


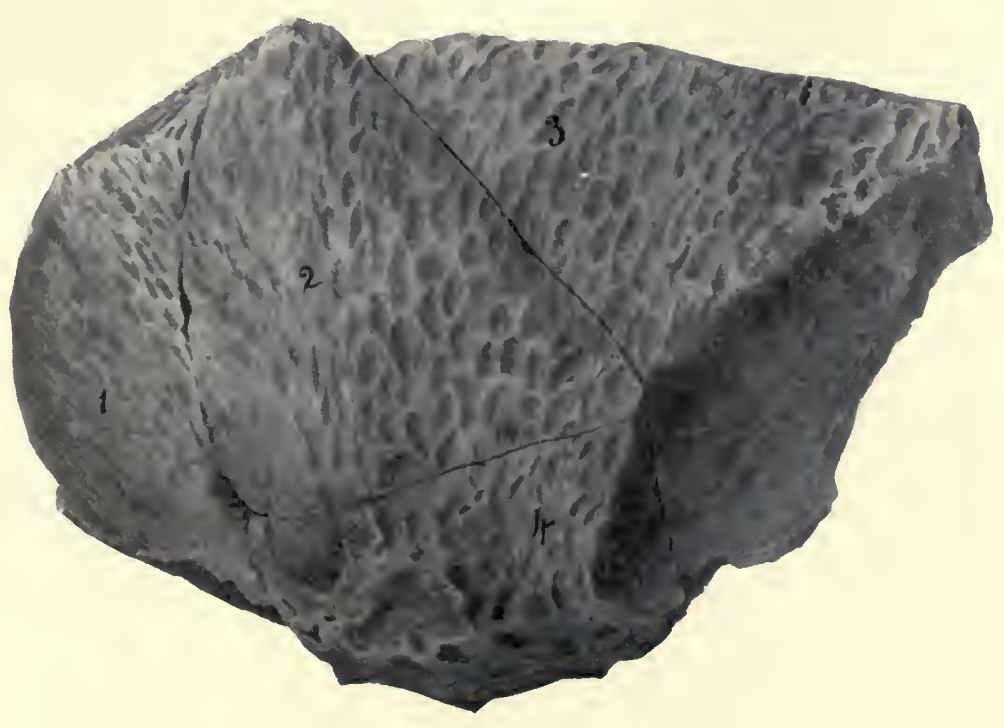

FIG. 1.

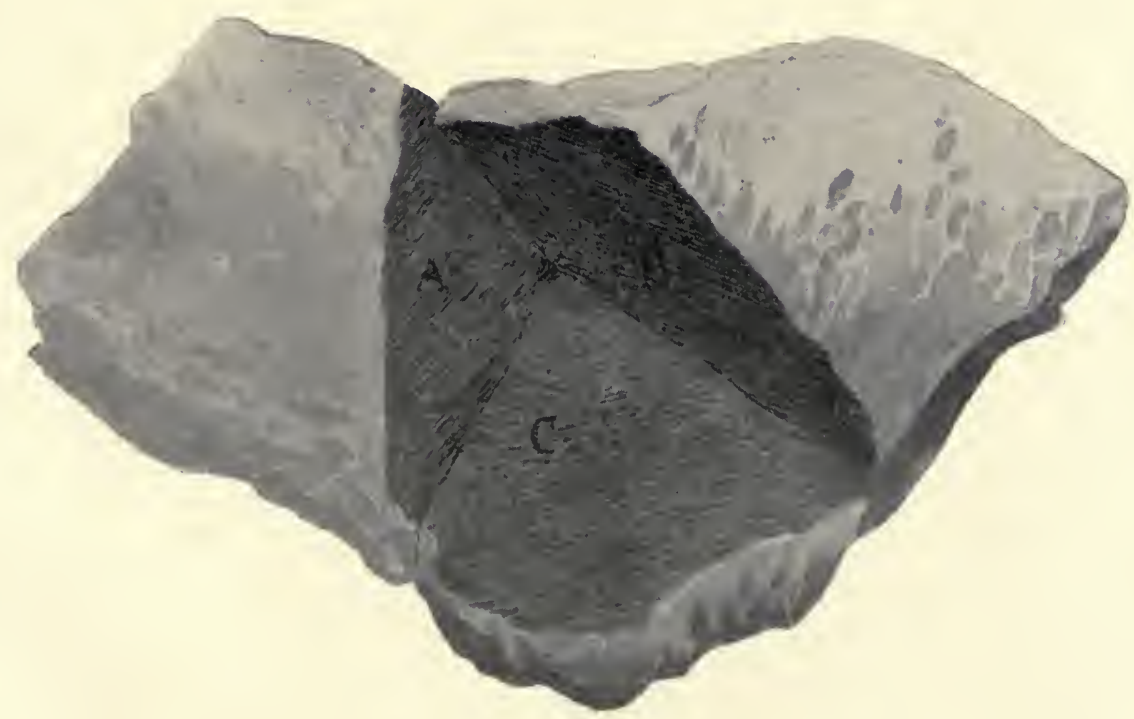

FIG 2. 
LIBRARY

UNIVERSITY OF ILLINOIS

URBANA 
The natural surface of the more conical part (Brustseite) of the meteorite as it is at present joined together, is for the most part deeply pitted with characteristic meteoritic thumb-marks (piezoglypten). These pits vary considerably, as would be expected, in form and size, but still exhibit a certain uniformity. The majority have the form of an elongated ellipse whose major axis is about twice the length of its minor. The following dimensions may be considered as representing a fair average of the size of the pits: Major axis, $3.2 \mathrm{~cm}$. ( $11 / 4 \mathrm{in}$.) Minor axis, $1.5 \mathrm{~cm}$. ( $5 / 8 \mathrm{in}$.) Depth, 3 to $10 \mathrm{~mm}$. ( $1 / 8$ to $3 / 8 \mathrm{in}$.) The depression of each pit generally slopes uniformly toward the center of the ellipse, but often there are to be found pits, the deepest point of which is quite eccentrically placed and which have a more or less conical shape. Some pits have a nearly circular outline as contrasted with the more common ellipsoidal one. These circular pits are usually of small size, but one of large size and unusual depth is to be found at the point in the meteorite where the two planes $A$ and $C$ cut each other. This pit has for the most part the shape of a deep regular bowl, although the regularity of one portion is broken by two smaller conical pits. The depth of this pit is $3.2 \mathrm{~cm}$. ( $\mathrm{I} 1 / 4 \mathrm{in}$.) and its diameter $6.4 \mathrm{~cm} .(2 \mathrm{~T} / 2 \mathrm{in}$.) The point of junction of the planes is almost exactly at the center of the pit. It is evident that this was a point of weakness in the stone at which the erosive action of heat and friction produced during the passage of the mass through the atmosphere worked more rapidly than on other parts of the surface. Its occurrence at the point of junction of the planes is pretty good evidence that the latter existed in the stone previous to its entry into the atmosphere. This fact has also a bearing on the disputed question as to the origin of the pits in general. It shows that they owe their origin chiefly to an excavation by heat and pressure of the softer or more friable parts of the surface of the mass which is acted upon. Wherever there is a point of weakness there a pit will be formed. Vice versa, where a pit is formed, there was a point of weakness.

The rear side (Rückseite) of the stone is not pitted. It has a well developed crust, but the encrusted surface exhibits no marked depressions or elevations. The only portion of the meteorite as now restored which illustrates the Rückseite is that appearing in the upper right hand part of Plate XLIII (Frontispiece). Here the surface is slightly undulating, but there are no pits.

The color of the crust of the meteorite is in general dark brown, but varies from almost black to light brown. At a little distance it appears perfectly smooth and in places shining, but on close examination it is seen to be quite uniformly and coarsely stippled by the pro- 
trusion of the more resistant grains. In many places, especially in the vicinity of the pits, minute thread-like markings appear over the surface, sometimes in parallel and concentric series, but more commonly in arborescent forms which are often quite elaborate. Theseseries or systems of markings do not appear to run in any common direction, but are differently oriented wherever found. I have noted no system more than one inch $(2.5 \mathrm{~cm}$.) in length, but several of about this extent. They resemble closely the lines of flow such as have been noted on the crust of the Stannern and other meteorites, and doubtless are of this nature, being formed by a minute portion of the substance of the meteorite becoming momentarily fused and flowing in a diversified path until cooled. Their course in some cases seems to mark the swirling of the same air currents which formed the pits. More extensive and larger ridges are to be observed over some portions of the crust. Three nearly parallel appear on the portion of the Rückseite just mentioned. Each is continuous for a length of from 3 to 5 inches. These do not appear to be of the nature of the lines of flow above mentioned, but more nearly resemble the veins which stand out on some meteorites and probably mark a line of more highly resistant constituents. Sections cut at right angles to the crust and examined with the microscope exhibit little if any alteration on the crust surface. The mineral outlines seem to be continued sharply up to the edge, and except for a certain smoothness of contour a crust surface could not be distinguished microscopically from the surface of an interior portion. Occasionally a metallic grain protrudes from the general outline, but so far as the contour as a whole is concerned it appears to be the result of erosion rather than of fusion.

The weathering which the mass has undergone since its advent upon the earth has affected it considerably. Even the larger fragments when broken open will be found to be deeply invaded by rust which has penetrated along cracks in every direction. Doubtless the great number of small fragments into which the stone was found to be broken when first discovered was due to this process of separation through weathering rather than to shattering caused by the blow of the mass upon the earth. The weathering has affected chiefly the metallic constituents of the stone, causing their oxidation, and this rust has penetrated and stained the meteorite deeply. The color of the weathered.surfaces has thus been changed from the dark green of the unaltered rock to various shades of brown, a characteristic color being a light yellowish brown, almost white, spotted with dark or rust brown.

The depth to which this discoloration has extended, except where 
it has followed cracks and fissures, is usually scarcely a millimeter, the color changing beyond this through reddish to black before the dark green of the unstained stone is seen.

Over a large part of the surface of the stone as found appeared a white amorphous coating which adhered very firmly. It could be removed by treatment with weak acid and most of it has been taken off in this way since the arrival of the stone at the Museum. When its substance is examined chemically it is found to be carbonate of lime containing a small percentage of clay. There can be little doubt that this coating is derived from the calcareous soil in which the stone lay for an unknown period, the carbonate of lime from the soil doubtless spreading over the meteorite surfaces through capillary attraction and cementing upon the-stone some of the surrounding clay. In some cavities of the stone a much greater proportion of soil is held, and at many points the cementing agent is iron oxide, derived doubtless from the oxidation of the metallic grains of the meteorite.

The unaltered stone when exposed by fresh fracture is of a dark green color, varying to black, although the latter shade may be due to staining from terrestrial oxidation. The stone is fine-grained, tough and compact. Occasional portions exhibit a slight porosity, giving a slag-like appearance. Such areas are however small and the pores of small size. The proportion of metallic ingredients is not large but they are quite uniformly distributed.

The metallic grains show most plainly on a polished surface, the distribution and quantity being illustrated in Fig. 3. Occasionally well-marked aggregations of these may be seen. None of the surfaces that I have examined show arrangement of the grains in lines or systems of lines such as have been noted in a number of stone meteorites by Reichenbach* and Newton $\dagger$. The largest metallic grain I have seen in the Long Island meteorite has a diameter of I.5 $\mathrm{mm}$. From this size all gradations may be found down to the minutest grains, examination with a lens bringing out many not visible to the naked eye.

The bronze-yellow color and comparative softness of many of the grains as exhibited on a polished surface mark them as troilite, in contrast to the silver-white color and greater hardness of those composed of nickel-iron. Further identification of the grains can be obtained by isolating them or by treating a polished surface of the meteorite with copper sulphate. On the polished surfaces examined the number of troilite grains is evidently much in excess of those of nickel-iron.

*Ueber das Gefage der Steinmeteoriten. Poggendorff's Annalen 1859, vol, 108, pp. 291-311.

†.Amer. Jour. of Science, 1893, 3rd ser., vol. 45, pp. 152-3. 
As individual grains they are, however, smaller in size. Often the nickel-iron and troilite can be seen to be intergrown in a single grain.

Before the blowpipe a fragment of the rock fuses even in the oxidizing flame with a fusibility of about 4.5 , the entire fragment blackening from the formation doubtless of $\mathrm{FeO}$. In the reducing flame the fusibility is, as would be expected, greater on account of a more rapid formation of FeO. Evidently the mixture of minerals forms an

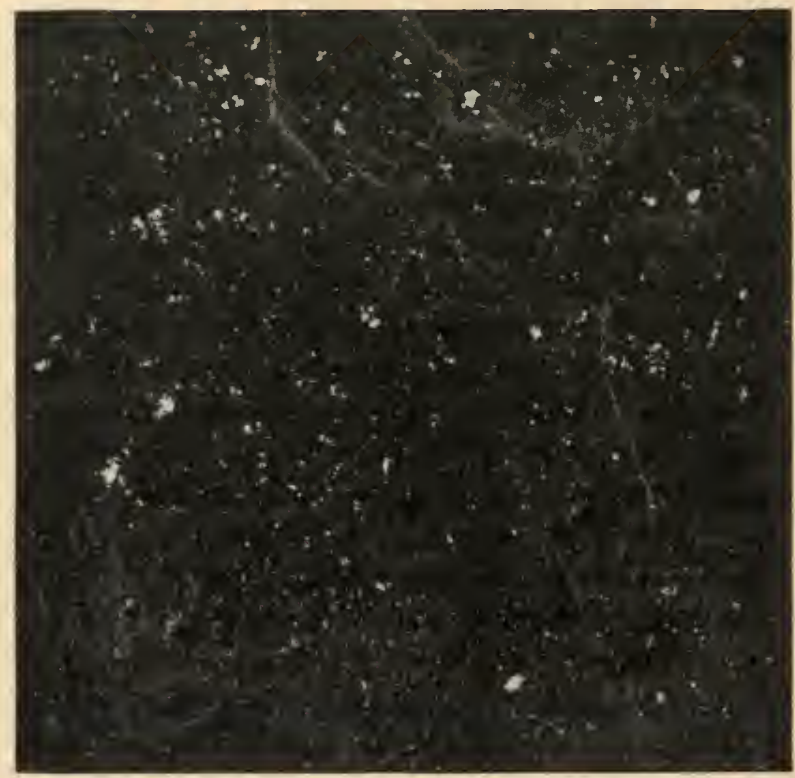

FIg. 3. Polished surface of Long Island meteorite showing size and distribution of metallic grains. Fully half of these are troilite. The light irregular lines mark the position of fractures of no significance. $\times y$.

aggregate fusible at a lower temperature than any of its components, for the component minerals are practically infusible:

The specific gravity of the stone, determined as an average of three separate portions weighing 50, 18 and 7 grams respectively, is 3.45 .

As previously stated, a description of the petrographic characters of the stone has been made by Weinschenk*, and as it seems desirable to collect here all the important literature bearing on the meteorite, a translation of Weinschenk's article follows:

"From the Long Island, Phillips County, Kansas, occurrence I 
have at my disposal four pieces, amounting in weight to $20-30$ grams. They possess a rusty weathered surface. Many hundred similar pieces were found (in part with crust), having a total weight of I, I 84 pounds. The meteorite of Long Island is a compact, dark stone, which appears dark green on fresh fracture and shows numerous metallic specks. The crystalline structure is megascopically visible; there are numerous shining cleavage surfaces and the meteorite resembles the fine-grained harzburgite from Riddles, Oregon. Chondri are only now and then to be seen. Under the microscope it is clearly seen that chrysolite and bronzite are the characteristic ingredients. The structure as well as the relations in quantity of the two constituents are very variable, the chrysolite now being in excess and now again the pyroxene, and the general porphyritic structure. passes commonly enough over to a purely granular one. Chondrus-like forms are found throughout, but they are seldom developed in an especially characteristic way. Ragged particles of metallic iron, numerous grains of iron sulphide (troilite?) and chromite complete its composition. The chrysolite occurs generally in porphyritic, more or less idiomorphic crystals, and in fragments. In the fresh condition it is colorless, but on slight heating it becomes reddish brown and pleochroic, and at red heat completely opaque, indicating a high content of iron. The cleavage of the mineral is always clearly developed, and this shows in many cases undulatory extinction. It is very rich in inclusions, generally appearing as dark-brown rounded forms which often show regular arrangement. In the weathered portions there occurs beside iron hydroxide, a serpentine-like substance as an alteration product of the chrysolite. The orthorhombic pyroxene is likewise colorless and transparent and may be classed as bronzite. It tends to form groups of larger individuals where the stone has granular structure; in smaller crystals it occurs also as a constituent of the ground mass in the porphyritic forms. Its distribution in the stone can best be seen if a section is treated with hydrochloric acid. This dissolves out the chrysolite but leaves the pyroxene unattacked. In sections so treated it can especially well be seen that the bronzite where it occurs as a constituent of the ground mass often exhibits skeleton growths which lie imbedded in a colorless substance and are not attacked by hydrochloric acid. This has weak refraction and between crossed nicols shows irregular illumination so that it is not improbable that it is a glassy substance possessing optical anomalies through strains. Rarely, besides the orthorhombic pyroxene there is to be seen a monoclinic augite in single grains, with the properties of diallage. The solid iron occurs in angular particles and often in 
zonal growths with chromite which also occurs alone, widely distributed in the stone. The little grains of the latter mineral appear brown, translucent. Also pyrrhotite (magnetkies) is present in considerable quantity and generally in large individuals. The structure of the whole stone indicates a cooling from a fused liquid, a view also supported by the porphyritic crystals of chrysolite and the skeletons of bronzite in the colorless base. There is no trace of breccia structure and the occurrence of few well-defined chondri gives no further proof. As has been often observed in meteorites, the whole stone has much more the character of a suddenly cooled mass, a character which is also indicated by the undulatory extinction of the chrysolite, the skeleton growths of pyroxene and the sudden variations in composition. The Long Island meteorite in mineralogical characters belongs to the harzburgites. If among terrestrial rocks we look for masses which in a structural and mineralogical way can be compared to the Long Island meteorite, it will be found that the number is a very limited one for the reason that rocks of similar composition have suffered in most cases much decomposition, by which their structure becomes indeterminable. But at all events it seems probable from the few observations on, for example, the terrestrial basalts of Greenland, that similar structures as they are here observed and in many other meteorites are formations characteristic of cooled rocks in which silicate of magnesia plays an important part, and that no grounds are given for the belief that formations of this kind in any of the terrestrial rocks have originated in any different way."

To the observations of Weinschenk there is little of importance to be added. The crystalline structure is perhaps hardly as prominent megascopically as one would judge from Weinschenk's account, while the chondritic structure is easily recognized in all the sections I have examined. There are numerous polysomatic porphyritic chrysolite chondri and typical fibrous ones of enstatite. One of the latter observed was $2.5 \mathrm{~mm}$. in diameter and it is evidently not cut through its center. A black, seemingly carbonaceous matter, borders its outer edge. The fibers are minute and lie in parallel groups extending in various directions. A porphyritic chrysolite chondrus seen had a diameter of $1.25 \mathrm{~mm}$, a single grain reaching the size of .025 $\mathrm{mm}$. Another monosomatic chrysolite chondrus seen was made up of chrysolite porphyritically developed in glass and with a distinct circular border of chrysolite all extinguishing simultaneously. This chondrus also contained a large grain of troilite. The crystal outlines of the chrysolite individuals whether developed in the chondri or out are often well defined, the predominant habit being short stout crystals 
bounded chiefly by pinacoids. The chromite more often has a red tone than the brown described by Weinschenk, its deep red grains being frequently seen in the sections. Both nickel-iron and troilite grains sometimes enclose small siliceous particles of what is probably chrysolite, indicating the latter to be the earlier formation.

As regards classification, the Long Island meteorite is classed by Wülfing as a crystalline spherical chondrite, Cck.* Beaver Creek, Bethlehem, Lumpkin, Menow, Prairie Dog Creek, Richmond and Savtschenskoje are other meteorites included in the same class.

Brezina classifies Long Island as a crystalline chondrite $\mathrm{Ck} ., \dagger$ in which group are included Erxleben, Klein-Wenden, Kernouve and many others. By Meunier, Long Island is put in Class 34, Erxlebenite, which includes monogenic meteorites of fine grain made up chiefly of chrysolite and bronzite and containing visible grains of nickel-iron. Bluff, Erxleben, Kernouve, Klein-Wenden, Menow and Pipe Creek are among the other meteorites brought by Meunier into this class. Thus the place of Long Island in classification seems to be quite generally agreed upon. Differences can, of course, be noted from other meteorites with which it is classed, it being, for instance, more compact and of finer grain than Beaver Creek and containing much less nickel-iron than Pipe Creek.

Of its well-marked crystalline character, however, there can be no doubt, nor, to my mind, of its monogenic origin.

Absorption by a siliceous magma, of iron in preference to nickel, seems to me to afford a reasonable explanation of the high percentage of nickel in the metallic portion of the stone shown in the following analysis. Such a high percentage of nickel in the nickel-iron of stone as compared with iron meteorites is common and must be of some significance. If the meteorite is simply tuffaceous in origin, one would expect the nickel-iron to have the composition of that of the iron meteorites uninfluenced by the accompanying silicates, but such is not the case.

Again, the outlines of the crystal individuals in the Long Island meteorite are sharply and fully developed and are in stable and magmatic position with reference to each other. Some of them are larger than the individual chondri and yet exhibit no sign of wear or fracture. Accordingly the believers in the tuffaceous character of all stone meteorites would find, I think, little to support their views in an examination of this stone. I can see no indications in its structure of any other origin than one of cooling in place from a fused magma,

*Die Meteoriten in Sammlungen, Tubingen, 1897, p. 453 .

†Die Meteoriten Sammlung des K.K. Naturhistorische Hofmuseums, IVien, IS95, F. 3ミ3. 
and this applies to the chondri as well as to every other part of the stone. In this view I agree fully with Weinschenk as quoted above.

An analysis of the meteorite was made by Mr. H. W. Nichols, Assistant Curator of the Department, in the laboratory of the Department.

For this analysis a fragment of the-meteorite free from visible oxidation was pulverized and dried at $100^{\circ} \mathrm{C}$.

A portion of 3.3863 grams was weighed out for the major part of the analysis, experiment having shown that better results could be obtained from portions of this size than from a larger portion of about 16 grams. The nickel-iron was separated by Eggertz's method of solution in iodine, the stone being found to be of too compact a nature to admit of magnetic separation even if the iodine method is not to be preferred in any case. The siliceous portion remaining was separated into two parts in the usual manner by treatment with dilute hydrochloric acid and potash. The separated portions were not weighed as it was found that sufficient oxidation occurred while burning off the filter to vitiate the results, but were analyzed separately and their weights calculated from the analyses. The insoluble portion was fused with sodium carbonate and a small amount of nitre. Silica was determined after the common method. Nickel and cobalt were separated from the iron by three precipitations and long digestion with ammonia and a large excess of ammonium chloride. Cobalt was separated from nickel by potassium nitrite. Nickel was titrated with. $\mathrm{KCn}$ and cobalt weighed as sulphate. Magnesium was weighed as pyrophosphate and calcium as oxide after an oxalate precipitation in the usual manner. Chromium was weighed as lead chromate after oxidation by bromine in acetic acid solution. Phosphorus was separated by the acetate process and weighed as molybdate. Water above $100^{\circ} \mathrm{C}$. was determined in a separate portion by Penfield's method of direct weight. Sulphur was determined in a separate portion as barium sulphate. Iron and insoluble alumina were determined in a separate portion, the iron being titrated by permanganate. The alumina was weighed directly, that of the soluble portion as alumina, that of the insoluble portion as phosphate. The alkalies were determined in a separate portion after separation by platinic chloride as usual. They were found to occur wholly in the insoluble portion. $\mathrm{TiO}_{2}$ was present in distinct although unweighable quantities. A precipitate of ammonium manganese phosphate also proved to be not quite large enough to weigh. A search for copper gave only a very faint brownish coloration with hydrogen sulphide which was not sufficient to verify. 
Mav, igo2. Meteorite STUIHE, I- FARRINGTON.

The analysis gave the following results:

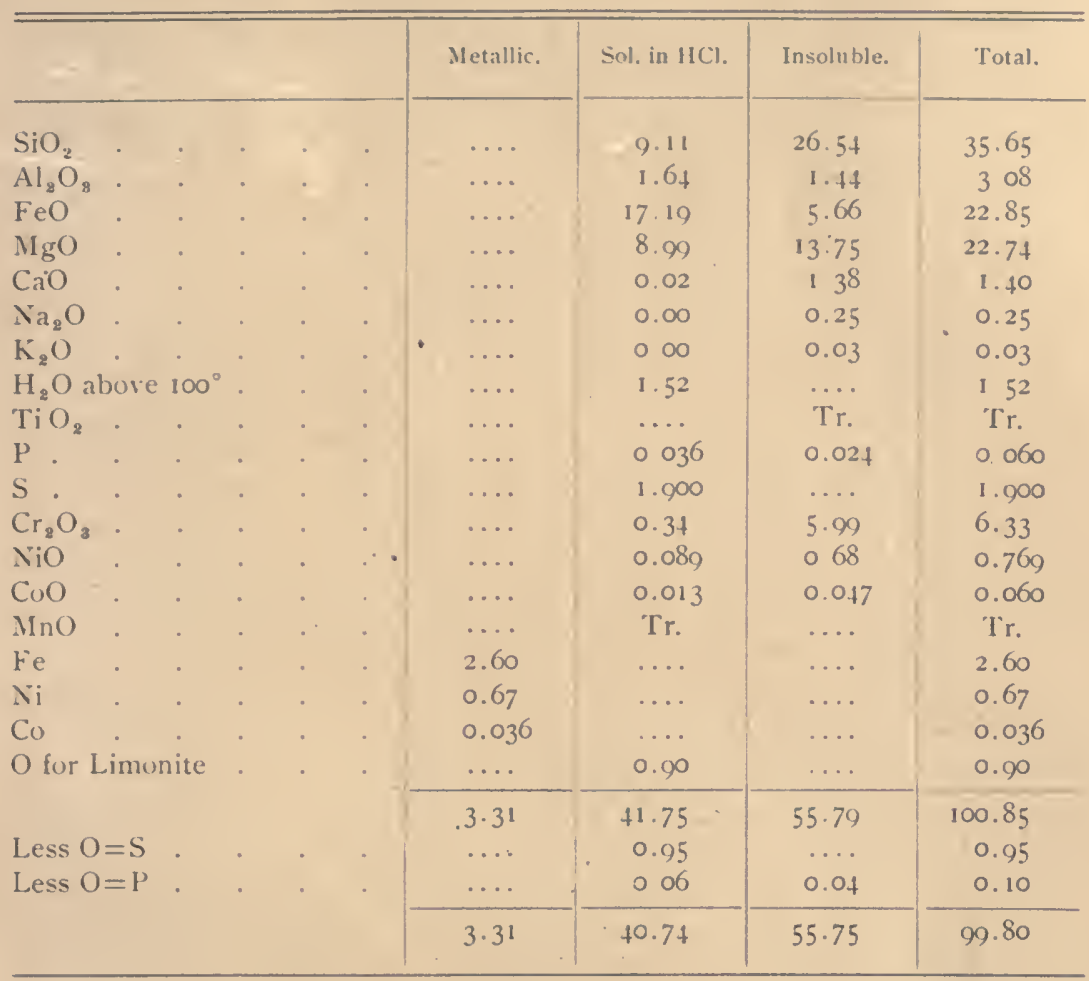

The most striking feature of the composition revealed by this analysis is the high percentage of $\mathrm{Cr}_{2} \mathrm{O}_{3} . \quad \mathrm{I}$ know of no other meteorite which shows so high a percentage, more than I per cent. being rare. Most of this was found in the insoluble portion and may hence be referred to chromite, especially as examination of sections with the microscope shows a large quantity of the red translucent grains which indicate that mineral. It may be worthy of remark, however, that the chromium mineral of the meteorite was more easily decomposed than ordinary chromite. Although left as an insoluble residue, after fusion with sodium carbonate, it went into solution on treatment with sulphuric acid without requiring a separate fusion with acid sulphate of potash. The percentage of $\mathrm{Cr}_{2} \mathrm{O}_{3}$ noted in the soluble portion of the meteorite may probably be regarded as a constituent of the chrysolite, although its quantity here is above the average.

The quantity of $\mathrm{Al}_{2} \mathrm{O}_{3}$, shown in the soluble portion of the above analysis, is unusually high and is difficult to account for. 
although it has not infrequently been reported by other analysts as a constituent of the soluble portion of meteorites.

Grouping the compounds of the above analysis which are known to enter into the composition of nickel-iron, chrysolite and bronzite, the following may be deduced as the probable composition of these three ingredients :

CONPOSITION OF NICKEL-IRON.

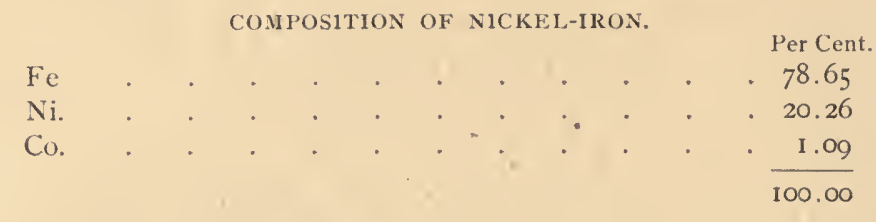

COMPOSITION OF SOLUBLE SILICATES (CHIEFLY CHRYSOLITE).

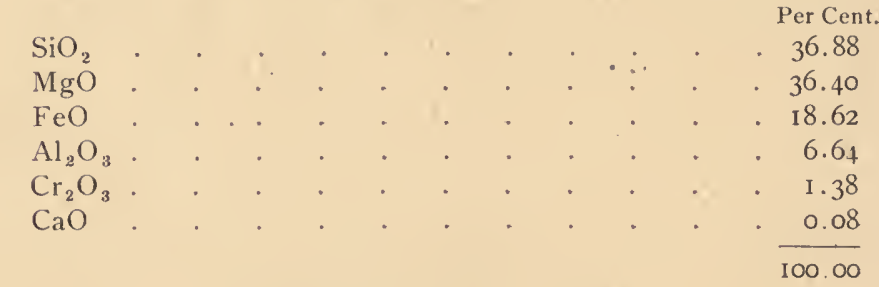

Ratio of $2 \mathrm{RO}: \mathrm{SiO}_{2}:: \mathrm{I} .9997: \mathrm{I}$.

COMPOSITION OF INSOLUBLE SILICATES (CHIEFLY BRONZITE AND MONOCLINIC PYROXENES).

Ratio of $\mathrm{RO}: \mathrm{SiO}_{2}::$ I:I.OI48.

Per Cent.

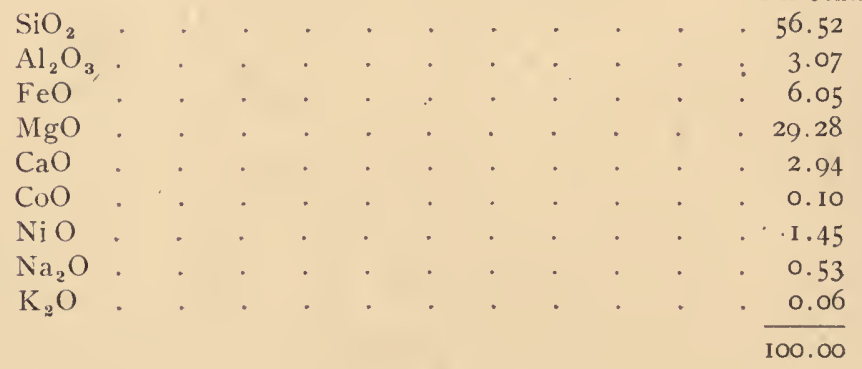

To place the alkalies in the pyroxenes, as is here done, is contrary to the usual custom, it being common to assume that they are present as feldspars. But as no feldspars could be detected in the slides and as alkalies are known to enter into the composition of pyroxenes in small amount, the conclusion here adopted seems the more reasonable one. No attempt was made to differentiate the two pyroxenes chemically, as I know of no guide for this. The amount of monoclinic pyroxene which can be seen in sections is very small, 
so that the above can practically be regarded as bronzite. It may seriously be questioned, however, whether digestion in hydrochloric acid can be relied upon to wholly separate the chrysolite and bronzite, for with longer digestion some of the bronzite is apt to go into solution, or, with shorter treatment, some of the chrysolite may not be decomposed. Further investigation of this subject should be made.

Taking all the probable ingredient minerals of the rock into consideration, the following is perhaps the best estimate that can at present be made as to its probable composition:

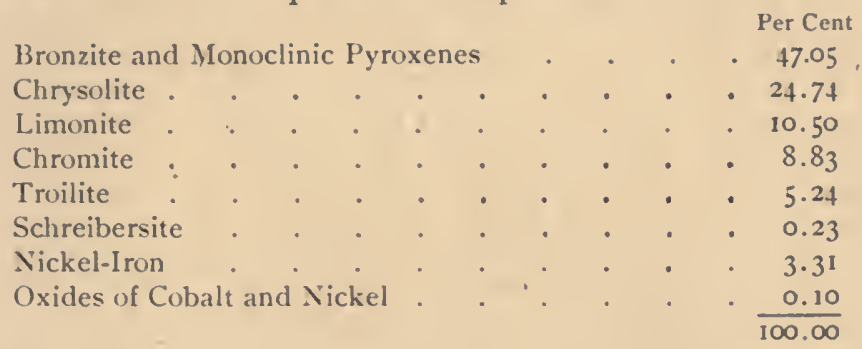

Here the limonite is probably of secondary or terrestrial origin and should perhaps be divided up about equally between the nickeliron and troilite in estimating the pre-terrestrial composition of the rock. The composition as shown above of about one-half bronzite accords well with what one can observe after treating a section with hydrochloric acid so as to dissolve out the chrysolite, for an extensive framework made up of bronzite then remains. The high percentage of chromite indicated by the analysis is also in accordance with observations made with the microscope.

The resemblance of the meteorite to terrestrial peridotites is, as noted by Weinschenk, very marked, and the constant association both in terrestrial and extra-terrestrial regions of the elements and minerals which compose rocks of this class indicates laws of association which are not yet comprehended.

\section{SUMMARY.}

I. The Long Island meteorite is a single isolated fall and fell as a single stone.

2. It is the largest single stone meteorite known.

3. It is traversed by planes resembling joint planes which are pre-terrestrial in their origin. 
4. In structure it belongs to the class of crystalline chondrites.

5. In chemical composition it is made up chiefly of oxides of silicon, iron, magnesium and chromium, with small percentages of iron, nickel, sulphur and minor constituents.

6. Its mineralogical composition may be estimated as $47 \%$ bronzite and some monoclinic pyroxene, $25 \%$ chrysolite, $9 \%$ chromite, and the remainder nickel-iron, troilite and schreibersite or alteration products of these. The content of chromite is remarkable and the highest yet reported in meteorites.

\section{NESS COUNTY, KANSAS.}

MUSEUM No. Me. 490.

Of this fall the Museum possesses one small complete individual having a weight of 85 grams. This aerolite in general form is wedgeshaped with angles but little rounded. Except for one fractured surface it is covered with a black crust or one which was undoubtedly originally all black, but through weathering has taken on in places a rusty brown appearance. The crusted surface is smooth but uneven, the irregularities suggesting pitting, although the depressions are not deep enough to produce pits of definite form. On making a section through the stone and polishing the surface thus exposed, the crust appears as a distinct black border having a thickness of about $1 / 4 \mathrm{~mm}$., in contrast to the dark brown color of the interior of the stone. In texture the crust does not differ noticeably from the interior, the porosity of many meteorite crusts not being in evidence. The dark brown color of the interior of the stone is doubtless largely a discoloration due to weathering. So completely has this discoloration penetrated the stone that it is impossible to find a place where the probable original color remains. The discoloration also makes it impossible to make out much regarding the structure of the stone megascopically, chondri not being visible on a polished surface. Metallic grains are numerous over the polished surface. They are for the most part of small size, the largest that I have noticed not being over $\mathrm{Imm}$. in diameter. They consist both of nickel-iron and troilite, the grains of the latter being distinguished by their yellow color and by not taking on a deposit of copper when immersed in copper sulphate. These troilite grains are quite as numerous as the grains of nickel-iron, but never as large.

In texture the stone is compact but it is only fairly coherent, 
breaking rather easily with a blow of a hammer. The specific gravity of the whole aerolite of 74 grams taken with the balance at $2 \mathrm{I}^{\circ} \mathrm{C}$. was found to be 3.504 . This value is of course slightly affected by the crust of the stone, but as a fragment without crust weighing 3.4 grams gave the same result the error from this cause must be very small.

Under the microscope the rock is seen to be a crystalline aggregate made up chiefly of grains of chrysolite, bronzite, nickel-iron and troilite. Here and there are traces of a structure which may indicate chondri or fragments of them, but such occurrences are rare. The chondrus-like structures lack definite outline and if of chondritic origin can only be considered fragments. One such fragment seen consists of alternate narrow lamellæ of about equal width, of chrysolite and glass. In another the lamellæ of chrysolite are broader and the mass has a border of chrysolite. Another suggests a portion of 'a polysomatic chrysolite chondrus. The grain of the stone as a whole is coarse, many of the chrysolite individuals reaching diameters of 0.2 to 0.4 millimeters. These incline to a porphyritic development, although the whole rock is crystalline. The chrysolite individuals are in general considerably seamed and fissured and stained brown from the penetration of iron rust. Where not stained they are colorless except for scattered minute black inclusions which occur in considerable quantity. They occasionally have prismatic outlines but are more often rounded or fragmental. Elongated fibers, alternating with glassy or half-glassy lamellæ also occur as previously noted.

A few well-marked aggregations of black, probably carbonaceous matter, occur mixed in a glassy or half-glassy ground mass, the whole having an approximately circular outline, and reaching in one case $0.5 \mathrm{~mm}$. in diameter. Here again a chondritic form is suggested but cannot be positively discerned. The carbonaceous matter is made up of smaller black particles not different from those included in the large chrysolite individuals.

The bronzite usually occurs in the typical fibrous development. It is colorless to yellow, the latter perhaps being due to iron stain.

Quite frequently large grains of an isotropic mineral appear which I cannot yet refer to any species with which I am familiar. The grains are marked by large size and freedom from inclusions and cracks such as characterize the other silicates of the meteorite. One grain seen has 0.7 sq. mm. of surface, another $0.5 \mathrm{sq} . \mathrm{mm}$., while the remainder are smaller. The outline of the grains is irregular and separated from the remaining constituents. Good cleavage is shown in some of the grains and is apparently cubic, although in one individual the planes 
meet at angles of $50^{\circ}$. The mineral is colorless inclining to a pink tinge. Relief and index of refraction about like that of chrysolite. I hope to give the mineral further investigation when a larger quantity is available.

The metallic grains (nickel-iron and troilite) have more or less angular outlines and incline toward elongated forms. The nickeliron and troilite are usually intimately joined, although grains of each mineral also occur alone. The troilite, readily recognized by its bronze yellow color, is more abundant than the nickel-iron.

A few opaque grains of black color closely associated with the nickel-iron and troilite are probably to be referred to chromite. Besides these, translucent grains with the typical red color of chromite are numerous, and one observed has a square outline showing it to be a section either of an octahedral or cubic crystal. The chromite always occurs united to the other opaque minerals. The grains of nickel-iron and troilite often enclose grains of silicates of small size.

On the whole the Ness County meteorite should probably be classed as a crystalline chondrite or Meunier's erxlebenite, although its chondritic nature is somewhat doubtful.

As is probably generally known, a number of small aerolites quite similar to the one here described have been found in Ness County. The first of these found was briefly described by Henry L. Ward.* Aside from this description and mention of the stones in one or two catalogues, no further account of them seems to have been published. Since Preston has suggested, however, $\dagger$ that the Ness County stones may belong to the same fall with Kansada, Jerome, Prairie Dog Creek and Long Island, a knowledge of them is desirable as a ground of investigating the suggestion. What additional facts I have been able to gain regarding the Ness County stones in general have been kindly given me by Mr. Henry L. Ward. In all at least twenty-five small aerolites have been found in Ness County, exclusive of Kansada. In weight they range, so far as Mr. Ward has been able to record them, from 34 to 3,467 grams, the total weight being I7, OII grams. This does not represent the entire amount, since of some stones Mr. Ward was unable to obtain exact record, but at least this amount has been found. The majority of these, so far as their place of find has been recorded, have come from the neighborhood of Franklinville, a village about five miles south of Ness City. The first one described by Mr. Ward, however, came from a place nearly twenty miles to the east of Franklinville, the exact locality being

*Amer. Jour. of Science, $4^{\text {th }}$ ser., vol. 7, p. 233. †Amer. Jour. of Science, $4_{\text {th }}$ ser., vol. 9, p. 112. 
given by Mr. Ward as Section 2, Township 20 S., Range 2r W. The village of Wellmanville is not far from this locality and this ærolite may therefore be called the Wellmanville stone.

For investigating Preston's hypothesis two lines of inquiry may be followed; (I) The probable course of the meteor and (2) the constitution and structure of the stones.

(I) The probable course of the meteor: Starting from Franklinville and going in a general northwest direction the Kansada and Jerome stones will be found nearly in the same line at distances of seventeen miles to Kansada and thirteen miles further on to the locality of the. Jerome meteorite.* Thirty miles further on in the same line appears the Oakley find. (See Plate XLV.) That a meteor may have moved along this line dropping fragments as it passed is conceivable, although no observed shower has a greater length of distribution than sixteen miles. If these stones are from a single meteor the direction of movement was undoubtedly from southeast to northwest rather than the reverse, since the smaller fragments would undoubtedly fall first. $\dagger$ The Wellmanville stone is somewhat eccentric to this general course but it is quite conceivable that it may have come from the same meteor so far as the latter's course is concernied. This would give a length of distribution of forty-six miles, or, if the Oakley stone is included, of eighty-six miles. The Long Island and Prairie Dog Creek meteorites evidently lie far outside of this course, although the exact location of the Prairie Dog Creek find seems not to be recorded. Brezina gives it + as $39^{\circ} 30^{\prime}$ N., $99^{\circ} 0^{\prime}$ W., on Sappa Creek, Decatur County, Kansas, which is an utterly impossible location. However, Prairie Dog Creek, Decatur County, may be assumed to be its approximate place of find. The Long Island and Prairie Dog Creek locations form then, as shown by Preston, in connection with the Jerome and Ness County stones, a parallelogram II 7 miles long by 35 miles broad. This parallelogram extends in a north-northeast direction, a course at about right angles to that which I have just traced. It is

* Dana, as quoted by Washington, states that the Jerome meteorite was found on the Smoky Hill River fifteen miles east of Jerome.-Amer. Jour. of Science, ${ }_{4}$ th ser., vol. 5, p. 447 .

f I do not know that attention has been called before to this method of deducing a meteor's course, but it seems evident as a matter of reasoning that the smaller fragments would reacb the ground first since the greater momentum possessed by the larger fragments would carry them farther. Meunier is of the opposite opinion (Meteorites, p. 424), but as a matter of record in all showers of which I have been able to obtain statistics the larger stones are found at the farther end of the meteor's path. This was the case at New Concord, Orgueil, Lance and Butsura. For the purpose of gaining further evidence on this point it is quite desirable that observers should in the future note the weight of the stones in connection with their location when picked up after a meteoric fall.

† Die Meteoriten Sammlung, etc., WVien, May 1895 , D. 359 . 
over this area that Preston suggests a meteoric shower might have extended. But an extension of a shower over an area so large, especially in width, would be quite unprecedented so far as present observations go. It seems to me, therefore, from a consideration of the probable paths, that Long Island and Prairie Dog Creek must be regarded as of separate origin from Ness County, Kansada, Jerome and Oakley, but that the four latter may, if only the paths are taken into consideration, belong to the same fall.

(2) The constitution and structure of the stones: On this point, unfortunately, little evidence is as yet at hand. As Preston remarks, the six finds are megascopically very similar. They are, all about equally oxidized and coated with carbonate of lime, indicating that they have lain about the same length of time in the soil, and are all of compact texture and possess about the same quantity of metallic grains except Oakley, which contains much more metal than the others. The crust of the large stones is, however, thin and darkbrown in color while that of the small stones (Ness County) is, except Wéllmanville, so far as I am able to learn, thick and black. This would indicate some difference in the character of the stones, but perhaps not sufficient to warrant considering them different falls.

From the point of view of structure, Weinschenk states that Prairie Dog Creek is sharply distinguished from Long Island*, for in Prairie Dog Creek the chondri are very numerous and make up the greater part of the stone, while in Long Island the chondri are obscure and the structure has a marked crystalline character. Taking into. consideration, therefore, their distance from the other finds and their differences from each other, there seems to be good reason for regarding Prairie Dog Creek and Long Island as separate single falls. Among the remaining four, Oakley, Jerome, Kansada and Franklinville, to which should perhaps be added Wellmanville as distinguished from Franklinville, Oakley seems on the whole to possess a distinguishing character in its larger quantity of metal. According to Preston's determination it contains $14.44 \%$ of metal $\uparrow$, presumably nickel-iron, while the percentage of metal (nickel-iron) in Jerome is, according to Washingtont, only $4.25 \%$. Oakley is also of coarser grain and possesses more bronzite than Ness County, as I have been able to learn by comparing microscopic sections.

Through the kindness of Dr. Washington I have also been enabled to compare a section of the Jerome meteorite with sections of Oakley and Ness County. Considerable differences are thus brought to light which make it very improbable that Jerome belongs to either of the

*Tschermak's Min. u. Petr. Mitth. vol, 14, p. 474.

†Loc. cit. 


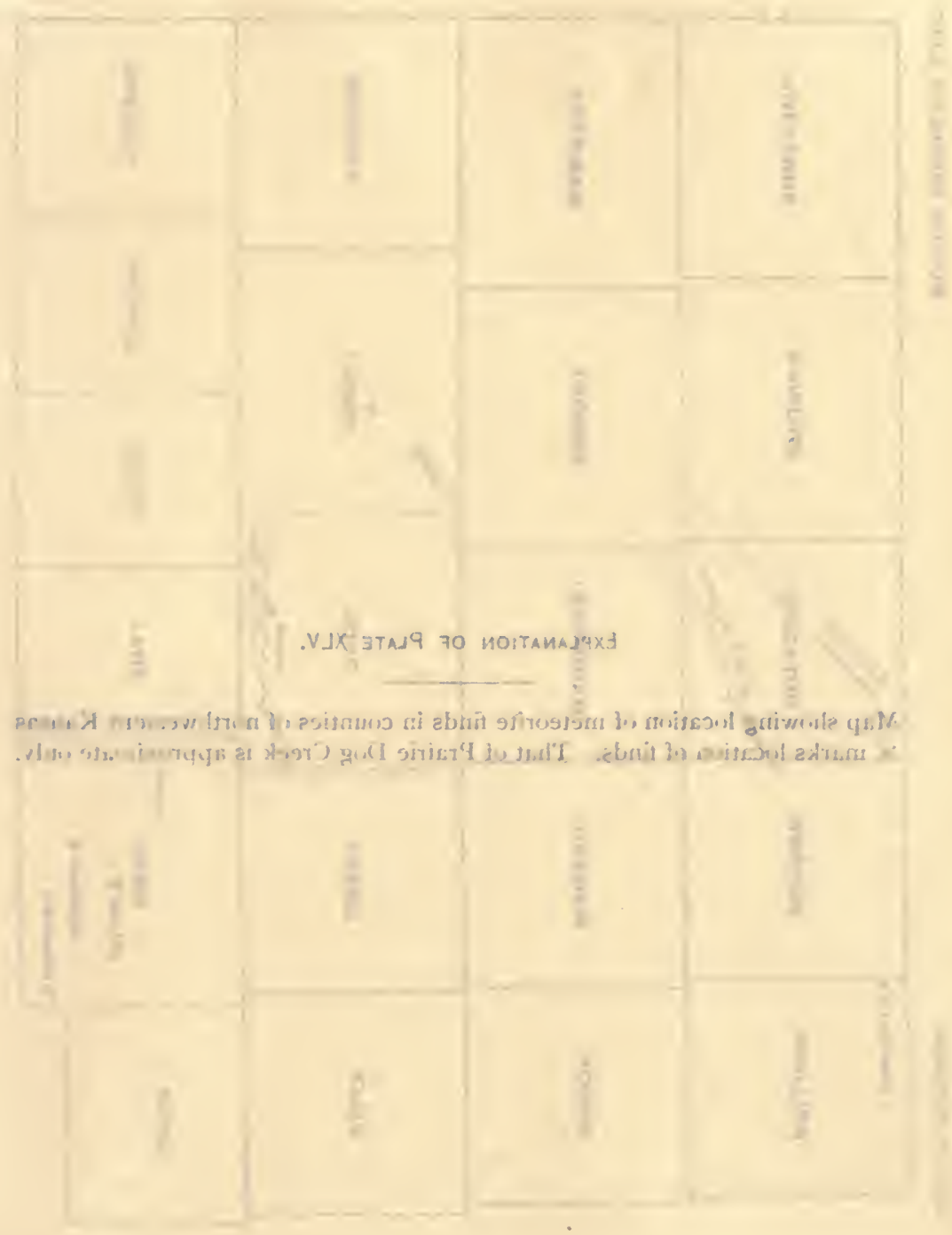




\section{Explanation of Plate XLV.}

Map showing location of meteorite finds in counties of northwestern Kansas. $X$ marks location of finds. That of Prairie Dog Creek is approximate only.

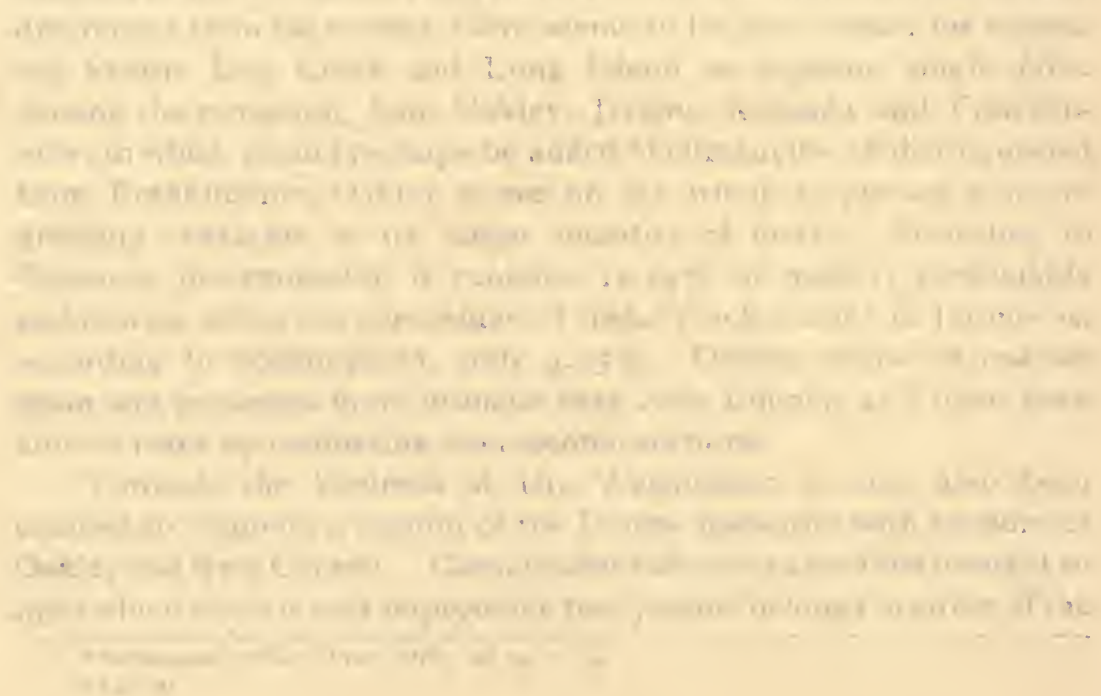




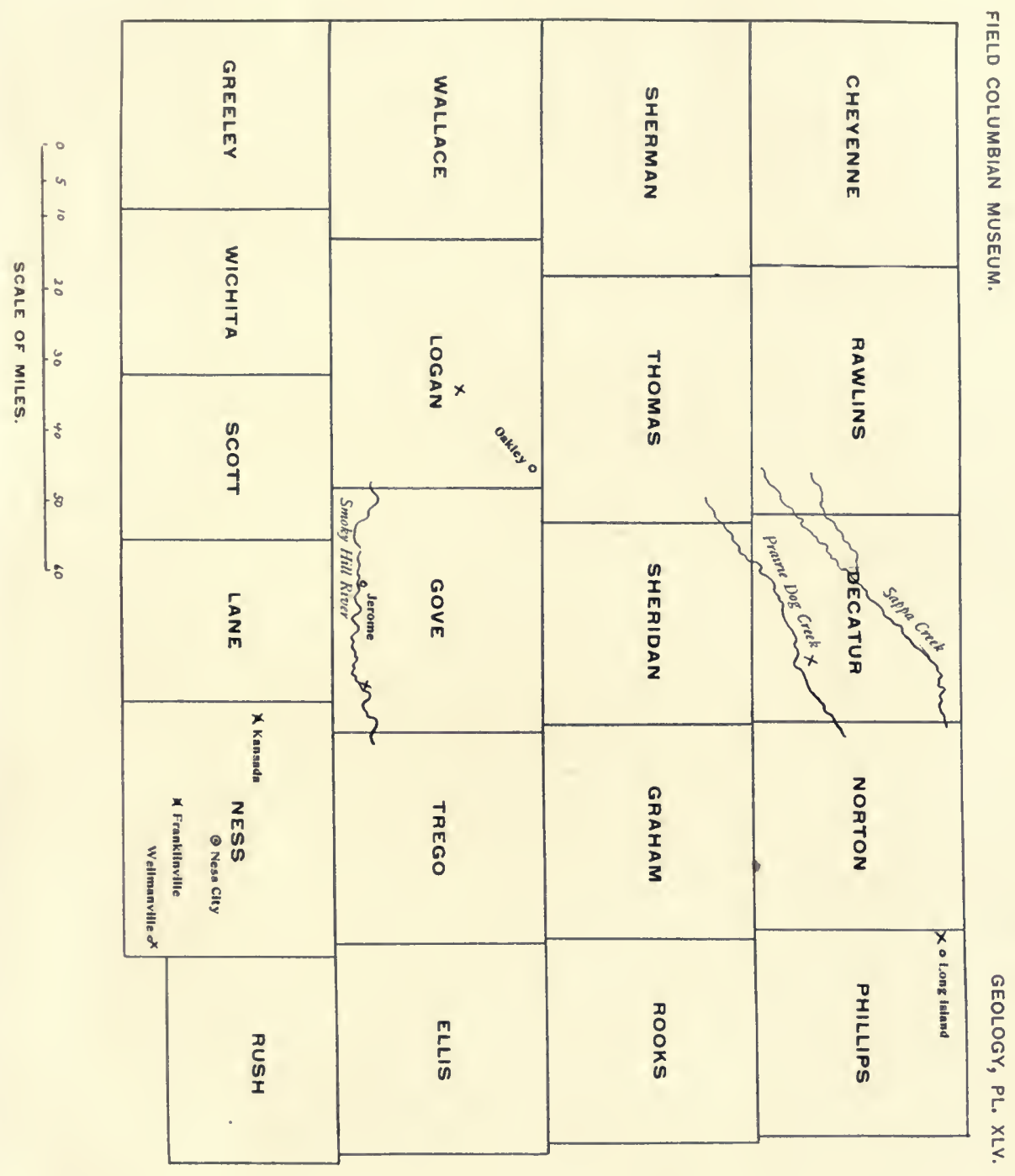


LIBRARY

UNIVERSITY OF ILLINOIS

Hagas.. 
other falls. Its structure is much more highly chondritic than that of either of the above, and the peculiarities of the chondri, which have been so fully described by Washington that they need not here be again enumerated, render them unique. There remain then only Kansada and Wellmanville to be compared as to structure with the other finds. Regarding these two, however, no further data can at present be obtained. No details as to their intimate structure have been published and I do not know the present whereabouts of the stones. It would not be surprising, when an opportunity for comparison presents itself, to find that Kansada could with good reason be connected with either Jerome or Franklinville and Wellmanville with Franklinville. Still, each might prove to be a separate fall, for as may be noted, there is no inherent improbability in supposing falls to take place within a short distance of each other at different times. The falls of Homestead and Hartford, Iowa, were, for instance, separated only about thirty miles and the character of the stones was not very different. The interval of time was twenty-eight years. Castine and Searsmont were separated by only about twenty miles in distance and twenty-three years in time. These are quite similar stones. The Estherville and Forest City falls were distant not over sixty miles from each other and took place within an interval of eleven years. Here, however, the character of the stones was quite different. Doubtless many other instances of falls approaching near each other in space and time could be found by searching. The citing of even the above is, however, sufficient to lead one to the conviction that classing together into one fall meteorites found in different localities is a work that should be performed with caution.

\section{TOLUCA (LOS REYES), MEXICO, D. F.}

MUSEUM No. Me. 454.

This meteorite was obtained for the Museum in the spring of 1897 from Mr. E. O. Matthews of the City of Mexico. It was brought him by some native Mexicans or peons who reported that they had found it some months before, at Los Reyes, while ploughing. This is all the evidence obtainable regarding the manner of its discovery. The meteorite is of the metallic variety (ärosiderite) and is a complete individual. Its weight entire is 43 pounds ( $19.5 \mathrm{kilos}$ ). Its form (illustrated by the accompanying cuts, Plate XLVI), is roughly that of a steep triangular pyramid whose greatest length is $24 \mathrm{~cm}$. ( $91 / 2$ inches), and greatest width $15 \mathrm{~cm}$. ( 6 inches). The sides of the pyramid are 
deeply hollowed and rounded so that the contours of the mass are curved, and at one of the edges it extends out in the form of a thin wing. On one side near the base are two especially deep and well-marked pits side by side, one somewhat conical in shape, the other broadly concave. The diameter of the conical pit is about $45 \mathrm{~mm}$. (I $3 / 4$ inches) and its depth $20 \mathrm{~mm}$. ( $3 / 4$ of an inch). The concave pit is about $63 \mathrm{~mm}$. (2 $1 / 2$ inches) in diameter and $12 \mathrm{~mm}$. ( $\mathrm{x} / 2$ of an inch) deep. These pits (fully shown in Plate XLVI) probably mark areas of schreibersite which were fused out during the passage of the meteorite to the earth. The surface of the meteorite is of a uniform dark brown color from oxidation, but the depth to which oxidation has penetrated is very slight, as the merest scratch with a file reveals the nickel-white color of the interior. The meteorite is not of the "sweating" variety and exhibits no tendency to further alteration.

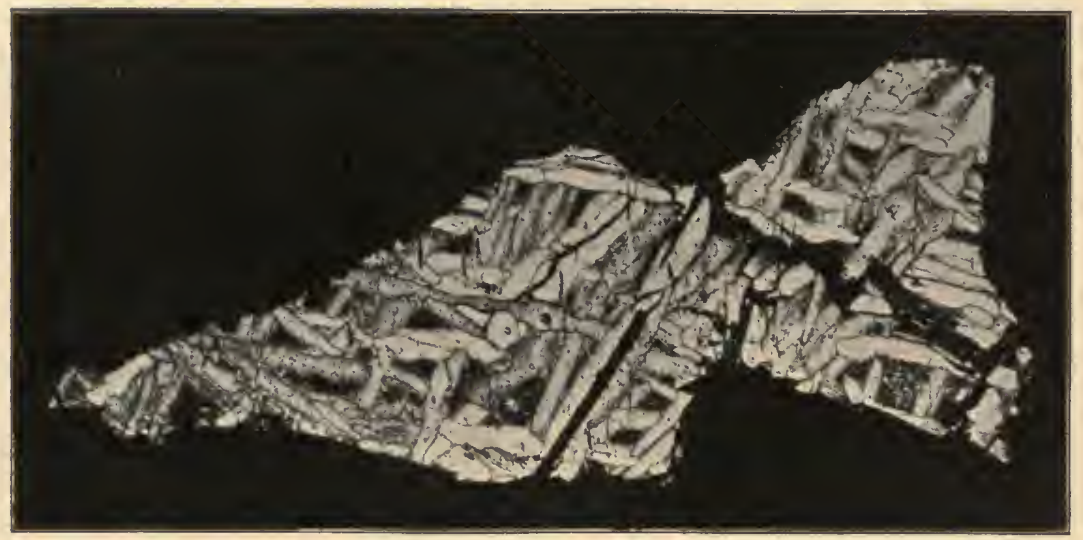

FIG. 4. Etched surface of Toluca (Los Reyes) meteorite, showing character of Widmanstatten figures. $\times \frac{3}{2}$.

Its substance is tough and malleable to a high degree. It is medium hard, cutting with some difficulty with a hack-saw. It takes a good polish, a polished surface being of silver-white to nickel-white color. Relative to copper sulphate the meteorite is active.

The iron has not been sliced, but a triangular area $6_{3} \mathrm{~mm}$. $\mathrm{x} 25 \mathrm{~mm}$. ( $2 \mathrm{I} / 2$ inches $\mathrm{x} \mathrm{I}$ inch) was made smooth and etched with nitric acid. The surface etched easily and exhibited well-marked Widmanstätten figures which are shown in Fig. 4. Two other smaller surfaces were also etched on other portions of the meteorite. The figures of the meteorite show that it is to be classed with Brezina's group 46 (Octahedrite with lamellæ of medium width) or Meunier's group 7 (Arvaite). The bands of the etching figures are not of uniform 


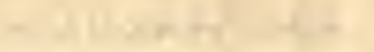
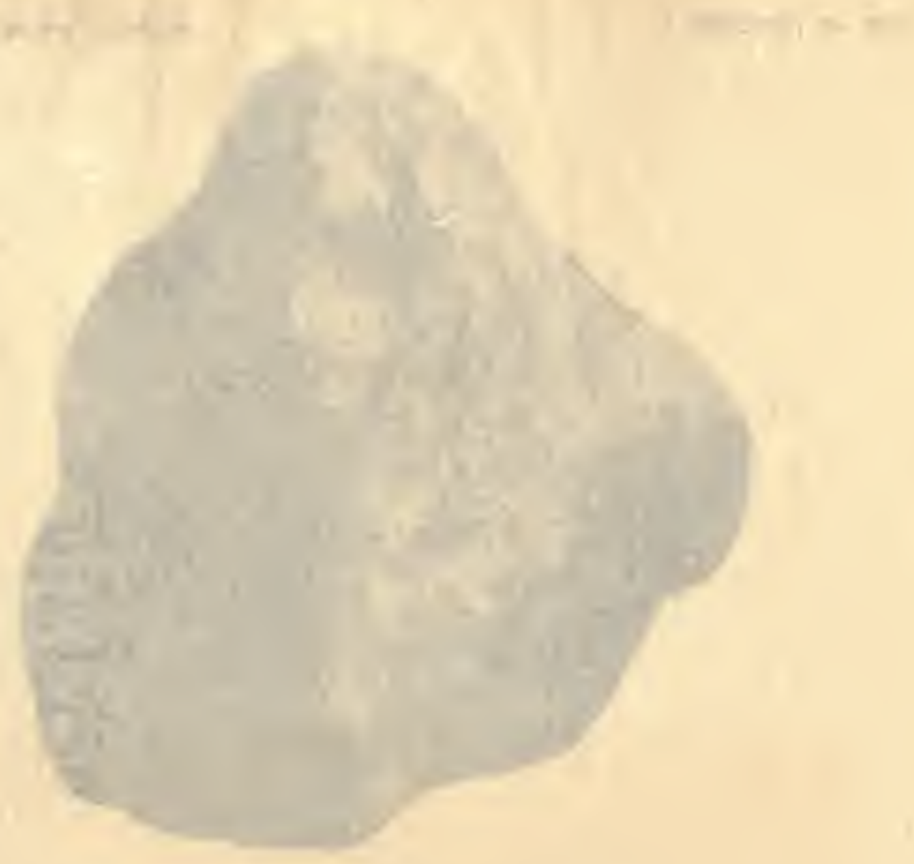

IVJX 3TAd9 70 no TAMAJ9KJ

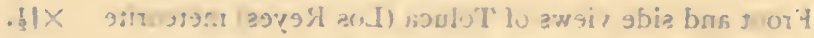

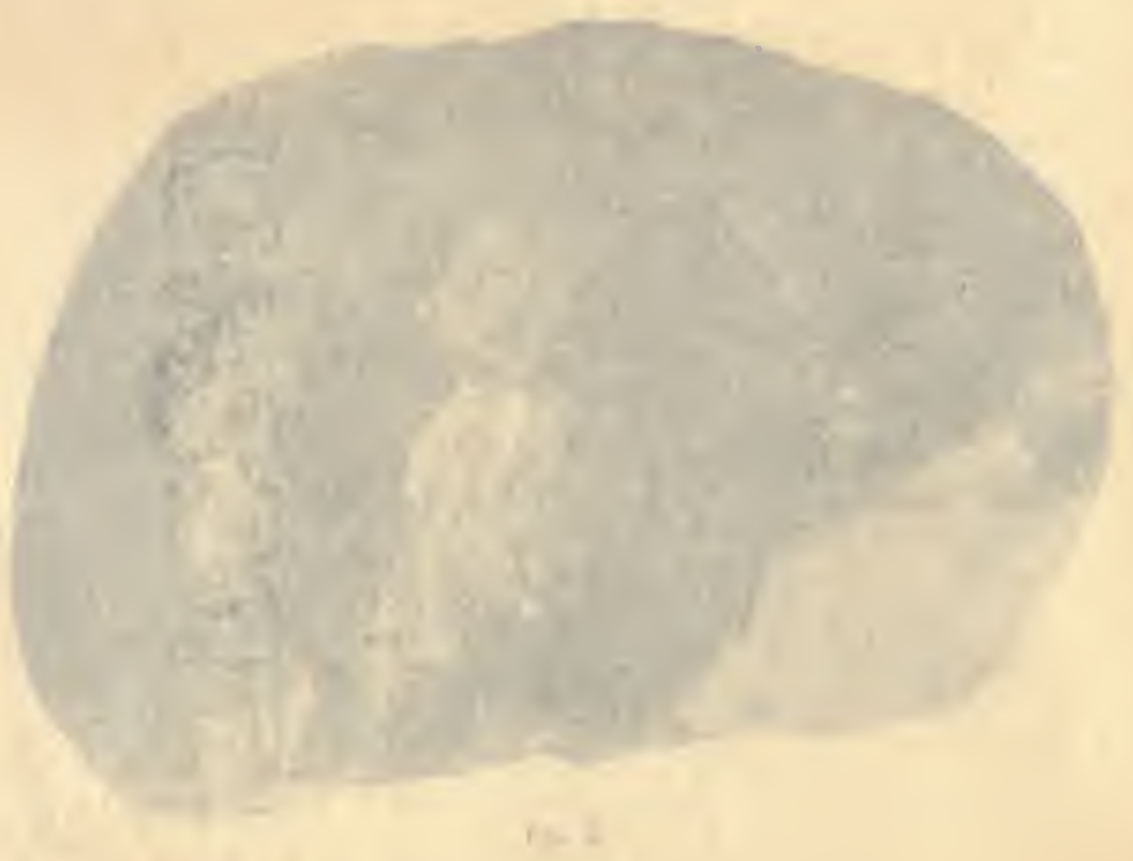



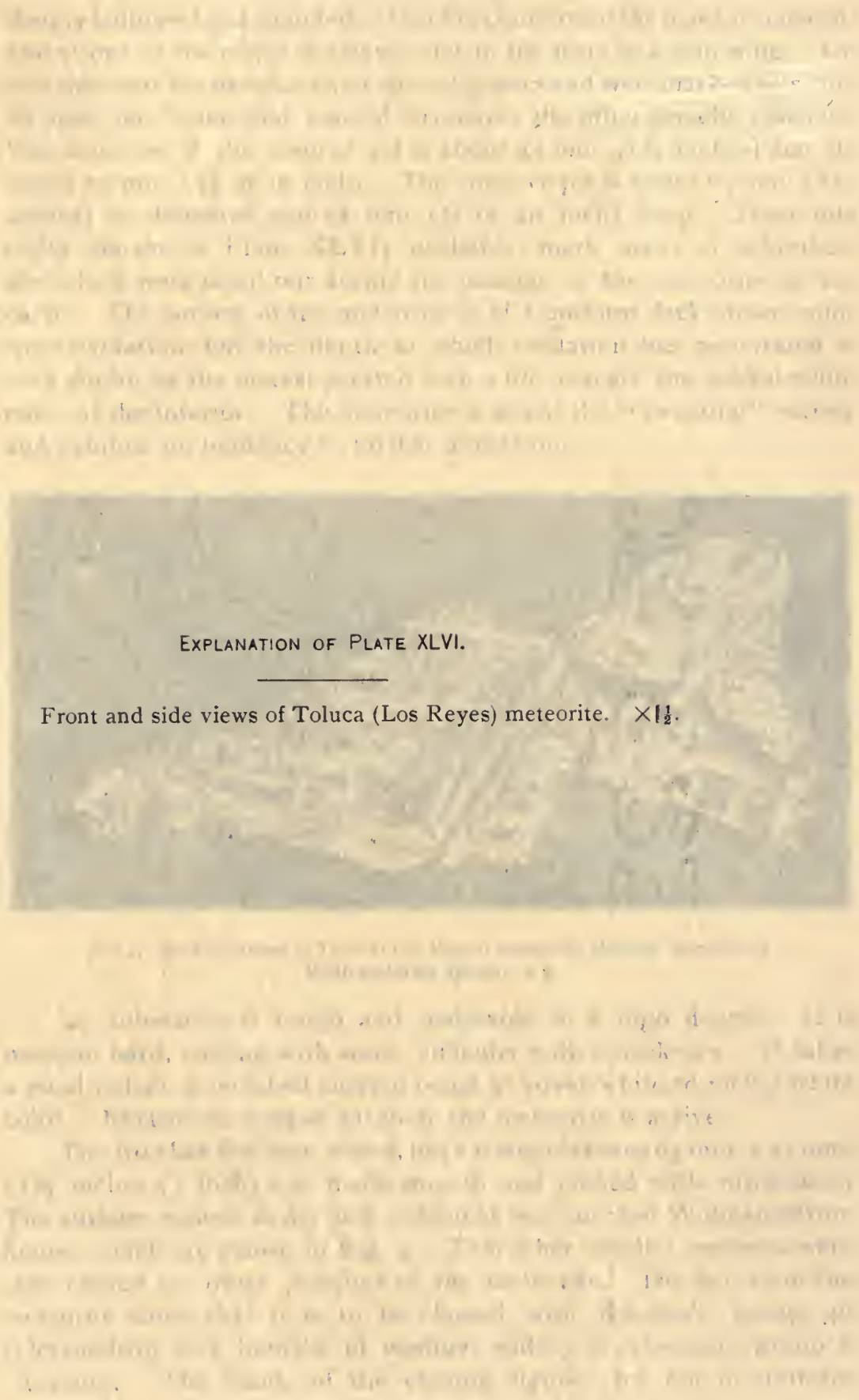


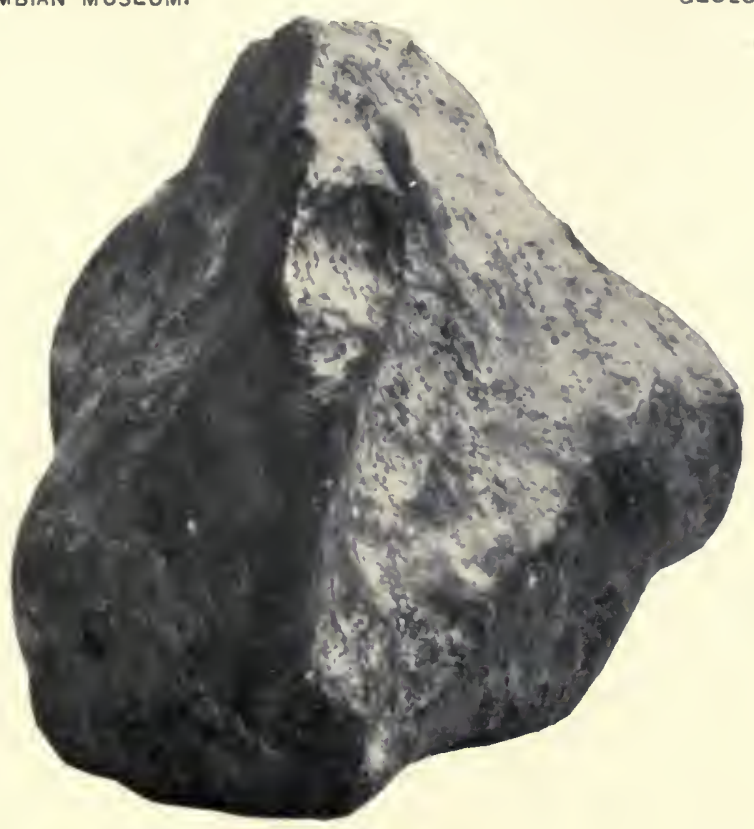

FIG. 1.

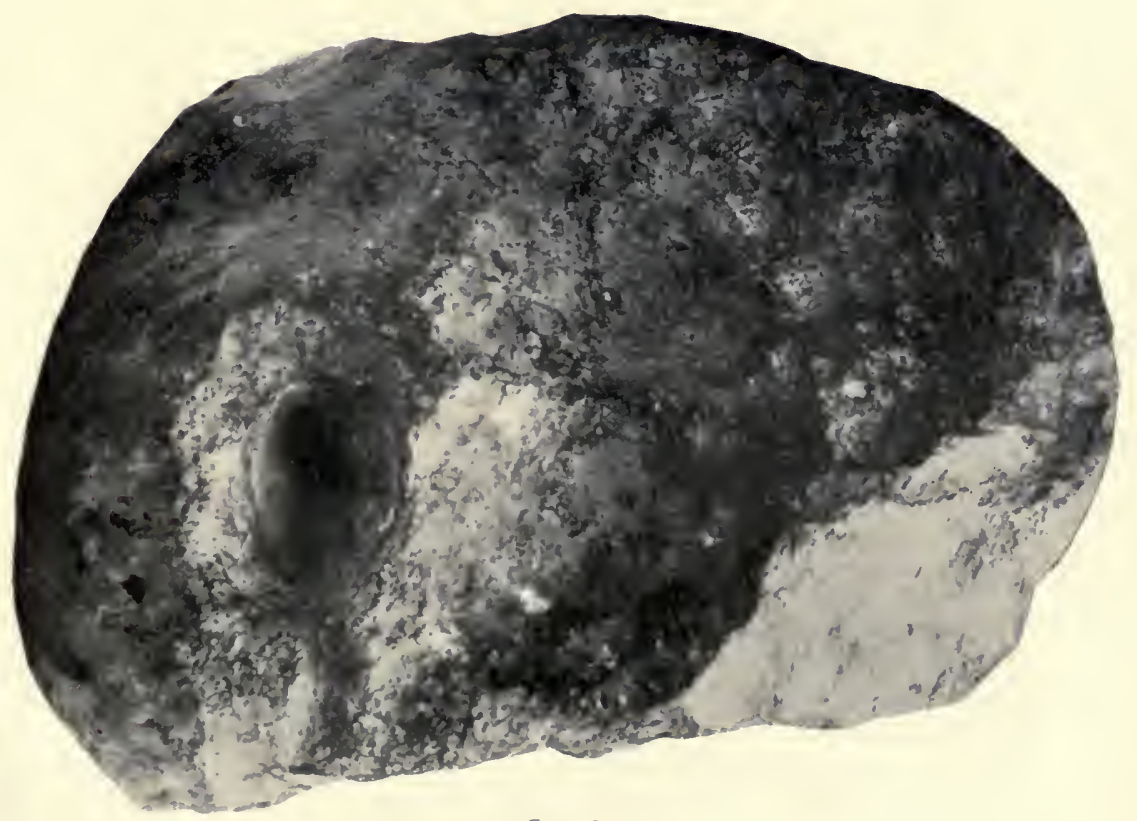

FIG. 2. 
LIBRARY

UNIVERSITY OF ILLINUIS

URAAHA 
width nor do they extend continuously for any great distance. They are of the type described by German writers as " wulstige" (swollen). The longest one on the etched surface figured accompanying is II $\mathrm{mm} .(5 / 8)$ of an inch in length and its contour is very irregular. Only the two alloys kamacite and tænite seem to be present. The former is iron gray in color and occasionally has a well-marked granular structure. The latter, filling the areas between the kamacite bands, is now more or less ribbon-like and now occurs in curvilinear areas. Much of it appears connected through the section, giving the impression of a network in which the kamacite is imbedded. It shades to a bronze color as contrasted with the iron gray of the kamacite and is left standing in relief by the etching. Under the lens its surface appears very rough, the etching of the acid acting upon it more irregularly than upon the kamacite. The only other mineral appearing in abundance in the meteorite is schreibersite, which occurs in long narrow bands or in irregular star-like forms. These areas are bounded by kamacite (swathing kamacite). Decomposition has taken place usually along the schreibersite bands, and these decomposed areas appear as dark marks on the etched surface.

Troilite seems to be almost entirely absent from the meteorite. Only two minute nodules are to be seen on the surfaces which have been etched and the percentage of sulphur obtained by analysis corresponds to a content of only $0.07 \%$. The presence of cohenite is indicated by the carbon found by analysis, but it was not observed on the etched surfaces.

An analysis of the meteorite was made by Mr. H. W. Nichols, the methods employed being briefly as [follows: Material for the analysis was secured by a boring made with a $1 / 4$-inch drill. The amount of substance used was 2.4353 grams. In order to prevent loss of sulphur and phosphorus the borings were placed in a flask and first treated with fuming nitric acid, to which they remained passive, and then hydrochloric acid was gradually added cold until solution was complete. Sulphur was weighed as barium sulphate. Phosphorus was determined by Eggertz's method as phosphomolybdate, the quantity being too small to allow of a magnesium pyrophosphate determination. Iron was separated by one ammonia and three basic acetate and one final ammonia precipitation. Manganese was separated by the sodium acetate method. Copper, cobalt and nickel were precipitated as sulphides in acetic acid solution, cobalt and nickel separated by potassium nitrite and all weighed from electrolytic deposition. Carbon was determined in an independent sample by oxidation in chromic acid after the method described by Blair.* 
The analysis gave the following results:

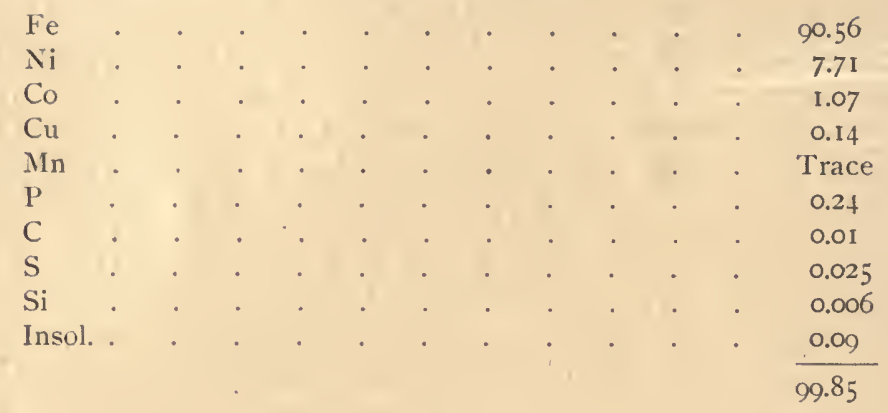

Omitting silicon and insoluble matter the analysis indicates that the meteorite has the following mineralogical composition:

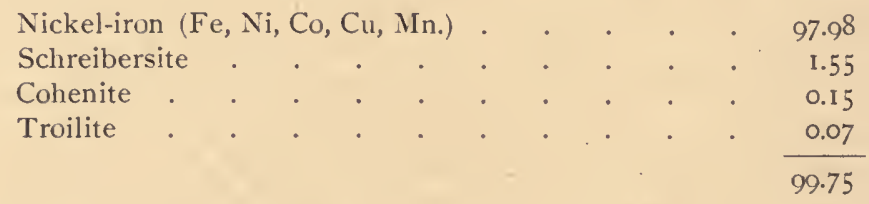

As the locality where the meteorite was found may be said in a certain sense to be in the vicinity of Toluca, it becomes an important question from the standpoint of the collector to determine whether the specimen is to be regarded a portion of the Toluca fall. Los Reyes is about forty miles (sixty-two kilometers) in a direct line east of Toluca. It is the little station at the southern end of Lake Texcoco where the Morelos division of the Interoceanic Railway joins the main line, about twelve miles southeast of the City of Mexico. On the same line of railroad twenty-five miles from the City of Mexico is the town of Ameca-Ameca, where the find of another iron meteorite has been reported by Castillo. * Castillo classes this iron with the Toluca meteorites, $\dagger$ and describes the "zone" of Toluca meteorites as extending from Ameca-Ameca on the east to Xiquipilco in the valley of Toluca [on the west]. If Castillo is right in this conclusion the Los Reyes meteorite comes within this zone, as Los Reyes is some fifteen miles (twenty-three kilometers) nearer Toluca than Ameca-Ameca. Castillo unfortunately gives no description of the -Ameca-Ameca meteorite by which its resemblance or otherwise to the known specimens from Toluca can be determined. He simply describes it as a "small nodule of meteoric iron found in the village [of

*Catalogue Descriptif des Meteorites du Mexique, Paris, 1889, p. 3.

$\dagger$ Op. cit., p. xr. 
that name] and now preserved in the National Museum of Mexico." If it is correct thus to group the Ameca-Ameca meteorite (and hence Los Reyes) with Toluca, a distribution of fifty or sixty miles at least must be conceded to this fall, Ixtlahuaca and Xiquipilco, the two localities in the Valley of Toluca where many of the Toluca meteorites are found, being ten miles farther from Ameca-Ameca than Toluca itself. It will be remembered that Fletcher, after a careful study of Mexican meteorites with especial regard to the supposed occurrence of widespread meteoritic showers, ${ }^{*}$ reached a negative conclusion as regards the wide extent of such showers, this opinion being similar to one in regard to such showers in general which he had expressed in an earlier paper. $t$ According to Fletcher the distribution of the Toluca meteorites as they have been reported from "localities distant from Toluca was probably due to human agency. With reference to the AmecaAmeca meteorite he states that "Ameca-Ameca is a town where there are now iron foundries, and where ploughs, castings, smoothing irons, mill wheels and other articles are manufactured," to show that Toluca iron might have been carried there for manufacturing purposes. With regard to this report of the state of manufacturing enterprises in Ameca-Ameca I fear that the distinguished authority of the British Museum has been misinformed, for I have spent weary days in the town without having learned of the existence of such industry.

The fact brought out by Fletcher to the effect that no knosun meteorite shower has a greater distribution than sixteen miles is a more important one in the study of this case, and the evidence at hand in this instance is hardly sufficient to enable us to assert that the Toluca shower had a wider extent.

The meteorite may of course have reached Los Reyes by the agency of man, but on the whole the indications are that it fell where it was found. The statements of the finders were plain and simple, the meteorite bears no marks showing any attempt to use it for economic purposes, and the price at which it was purchased was lower than any one who had brought it from Toluca would probably have sold it for. If the iron fell where it was found it is important to determine whether it was an independent fall or whether its resemblance to known Toluca irons is sufficient to make it probable that it fell at the time of the Toluca shower. Here again no positive evidence is at hand, but the chances are, in my opinion, in favor of the latter conclusion. The meteorite certainly does not differ sufficiently from known Toluca irons so that its independent origin can be asserted, 
and on the whole it resembles them considerably. Published analyses of Toluca irons give percentages varying somewhat widely, within which limits the Los Reyes values may certainly be included. For purposes of comparison of analyses, several that have been made of Toluca irons by different authorities are given below:

I. Taylor, American Jour. Sci., 3d ser. XXII. 374. 1856.

2 and 3. Pugh, Annal. der Chem. and Pharm. XCVII. 385. 1856.

4. Nason, Jour. Prakt. Chemie. LXXI. 123. 1857.

\begin{tabular}{|c|c|c|c|c|c|c|c|c|c|c|}
\hline & $\mathrm{Fe}$ & $\mathrm{Ni}$ & Co & $\mathrm{Cu}$ & $\mathrm{Mn}$ & S & $\mathrm{C}$ & $\mathrm{P}$ & $\mathrm{X}$ & \\
\hline I. & 90.72 & 8.49 & 0.44 & $\ldots$ & $\ldots$ & $\ldots$ & $\cdots$ & 0.18 & $\begin{array}{l}0.63= \\
\text { Insol. }\end{array}$ & 100.46 \\
\hline 2. & 90.74 & $7 \cdot 78$ & 0.72 & 0.03 & & 0.03 & . & 0.24 & $\begin{array}{c}\text { residue. } \\
0.34= \\
\mathrm{X}\end{array}$ & 99.88 \\
\hline 3. & 87.89 & 9.06 & 1.07 & $\ldots$ & 0.20 & $\ldots$ & .. & 0.62 & $0.22=$ & 99.06 \\
\hline 4. & 90.133 & \multicolumn{2}{|c|}{7.241} & & & Tr. & & 0.376 & $\begin{array}{l}2.225= \\
\text { Insol }\end{array}$ & 99.975 \\
\hline Los Reyes & 90.56 & $7 \cdot 71$ & 1.07 & O.I4 & Tr. & 0.025 & 0.01 & 0.24 & 0.096 & 99.85 \\
\hline
\end{tabular}

The resemblance in chemical composition to the average of T.oluca irons is thus seen to be close. Further, the etching figures come within the limits found in Toluca irons, since these vary considerably in detail as is well known. The meteorite will be designated, therefore, as Toluca (Los Reyes).

\section{HOPEWELL MOUNDS, ROSS COUNTY, OHIO.}

MUSEUM No. Me. 480.

Among the objects obtained from the Hopewell Mounds of Ohio, and now in the Anthropological collections of this Museum, are a number made of iron. These include a part of a head and ear ornament, some celts, a number of beads, and lastly a small unwrought mass weighing about I30 grams (5 ounces). Dr. G. A. Dorsey, to whom I am indebted for calling my attention to them, informs me that they were all found associated with a single human skeleton near an altar of one of the mounds. They were considerably oxidized, so that the original metal is in most cases obliterated, but the unwrought mass above mentioned was found to be oxidized only on the surface. A quali- 
tative analysis of some filings from this mass showed the presence of nickel and indicated, as might be expected since no other source of iron probably lay open to the Mound Builders, that the objects were made of meteoric iron. Upon removing the rust from one surface and submitting the area so exposed to the etching action of nitric acid, the meteoric nature of the iron was proved beyond question by

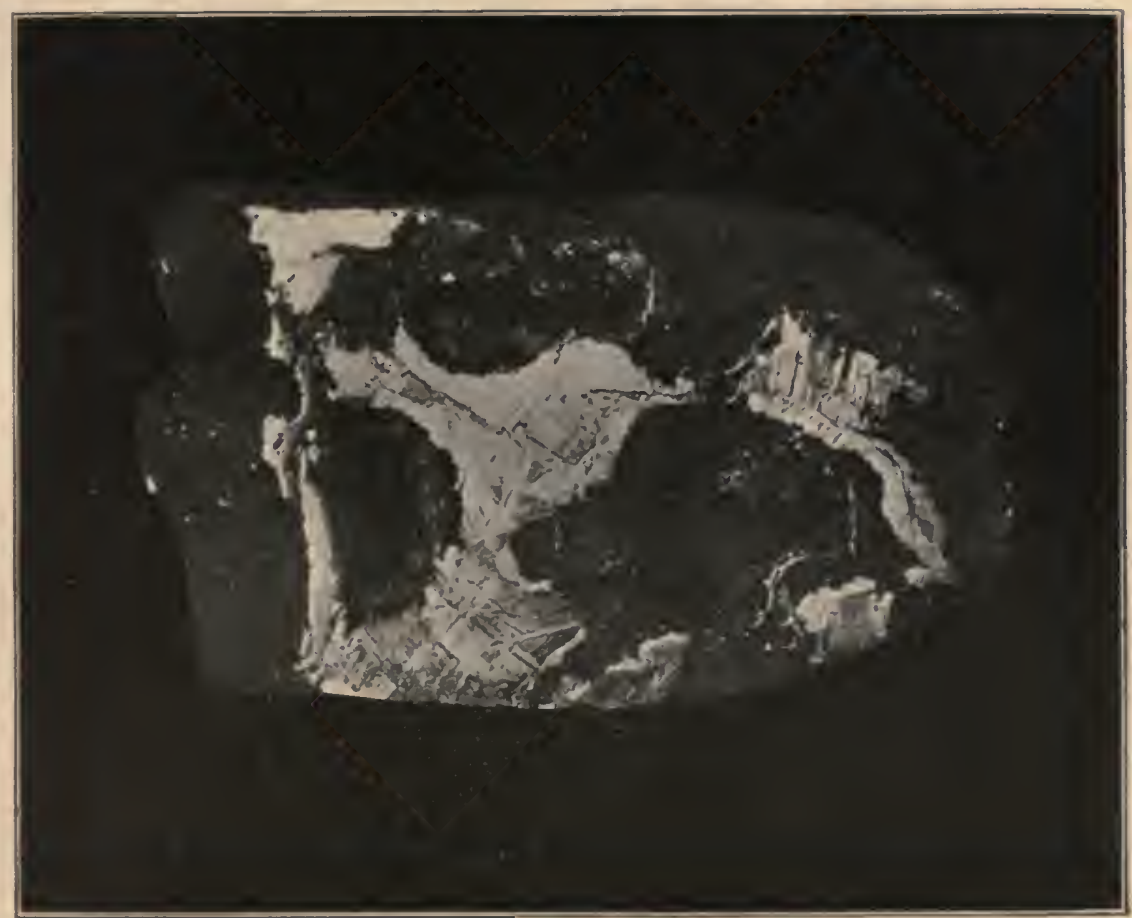

Fig. 5. Outline of Hopewell Mounds meteorite, with etched portions showing curving of the lidmanstatten figures, probably due to heating and hammering that the mass has received. $\times \frac{5}{2}$.

the appearance of Widmanstätten figures. The nature of these figures is shown in Figs. 5 and 6, where the structure of bands of kamacite separated by thin ribbons of tænite can be plainly discerned. The width and continuity of the kamacite bands varies considerably. Some are at least a millimeter in width and from these they grade down to not over twice the width of the corresponding tænite ribbon. While many are continuous in a general way for a length of from 10 to 20 millimeters, the tænite runs through them all in a series of anastomosing branches and in places gives the impres- 
sion of a network in which grains of kamacite are imbedded. The contour of the figures is for the most part curved and wavy, especially near the borders of the section. The most reasonable explanation for this seems to be the treatment probably given the mass by the ancient workmen. If heated until it became somewhat plastic and then hammered, just such curving of the plates might be produced. Owing to the distortion of the figures it is impossible to positively classify the iron. Apparently it is an octahedral iron having lamellæ of medium width. While two alloys, kamacite and tænite, are plainly discernible, no troilite or schreibersite can be seen,

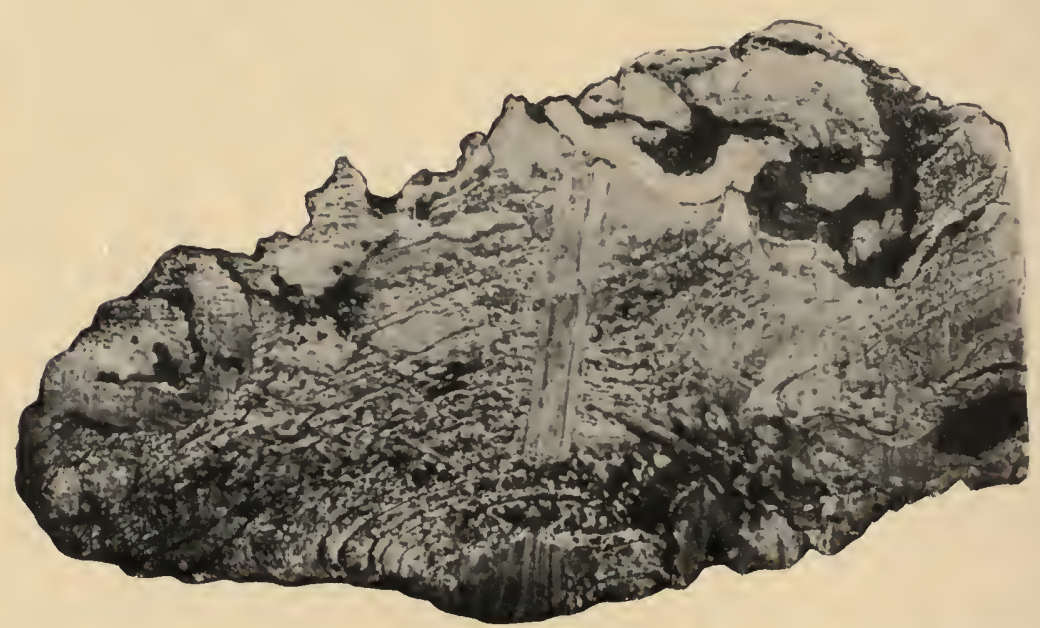

FIG. 6. Etched surface of Hopewell Mounds meteorite showing Widmanstatten figures curved and interwoven, probably on account of heating and hammering that the mass has received. $\times \frac{5}{2}$.

although the presence of the two latter is indicated by the percentages of sulphur and phosphorus found on analysis. At one end of the mass are three large irregular pores such as might have been produced by the falling out of crystals of chrysolite or other stony matter. There is no other evidence, however, that such stony matter was at one time present and the cavities may have been produced in a purely mechanical way. This seems rather the more probable from the fact that the rest of the mass is quite compact. The iron is rather soft, cutting easily with a hack-saw, and malleable. It is active to copper sulphate.

For purposes of quantitative analysis a small piece was sawed from one end of the mass and cleaned from rust by filing and scraping. 
The analysis, made by Mr. H. W. Nichols, and using the methods noted above for the Los Reyes meteorite, gave the following results:

Amount of substance taken, 2,i66.3 grams.

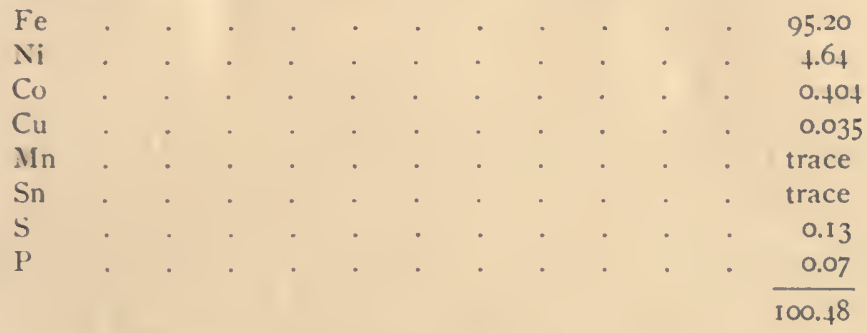

The other meteorites known to have been found in Indian mounds of this country are those of Octibbeha County, Mississippi, and the Turner Mounds, Ohio. In the Octibbeha County iron the quantity of nickel reaches $59.7 \%$, and this sufficiently distinguishes it from any other known meteorite. The Turner Mound meteorites include masses from two different mounds, which were analyzed by Kinnicutt* with the following results:

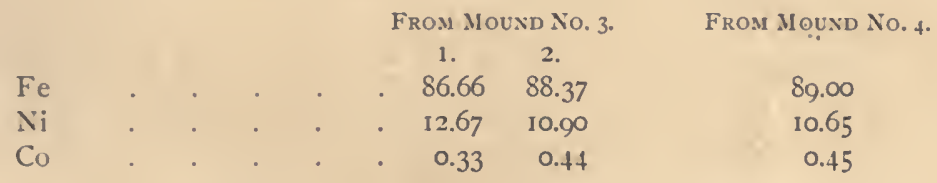

It will be remembered that Kunz concluded from a comparison of the Turner Mounds meteorites with those of Kiowa County, Kansas, that on account of the marked similarity in constitution and structure they belonged to the same fall.* The Hopewell Mounds are only about seventy-five miles distant from the Turner Mounds in an easterly direction, and it might be expected that the same meteoric iron would have been used for the construction of the objects found in these mounds. The results of the analysis above given do not, however, permit this conclusion, the differences in the percentages being greater than are known to occur among the individuals of a single fall. Comparison of etching figures is out of the question on account of the distortion of those of the Hopewell Mounds specimen, but the lack of any-content of chrysolite such as characterizes the Turner Mounds

*Reports Peabody Museum of Archæology, vol. 3, p. 382, et seq.

*American Journal of Science, 3rd series, vol. 40, pp. 316-318. 
masses is a further point of difference. It seems impossible at present therefore to connect the Hopewell Mounds mass with any known meteorite and the specimen will therefore be designated as the Hopewell Mounds meteorite.

\section{TAENITE FROM THE KENTON COUNTY METEORITE.}

One of the sections of the Kenton County, Kentucky, meteorite in the Museum collection (Museum No. Me. r34), tends to decompose along the planes of structure marked by the Widmanstätten figures. The result of this decomposition is a separation of the mass into fragments bounded by octahedral planes, of a homogeneous alloy of irongray color between which lie thin, elastic plates of a tin-white color. The first alloy is undoubtedly kamacite, the second taenite. In order to compare this taenite with that known from other meteorites, some study of it was made. The fragments which it was possible to separate rarely exceeded four square millimeters in surface. As plates, they were thin, elastic and magnetic. The only feature noted regarding their surface was that it is often marked by parallel rows of minute ridges extending across the plate. Corresponding striations isually appear on the adjacent kamacite. The plates are soluble in copper ammonium chloride, and fusible with difficulty B.B.

In separating plates for analysis care was taken to use only those which could be completely isolated and showed"no rust. This proved a laborious operation, and after considerable toil the amount that could be secured for analysis was only 0.022 grams. The analysis was made by Mr. H. W. Nichols. Iron was determined by titration with an $\mathrm{n} / \mathrm{I} 0 \mathrm{O}$ potassium bichromate solution, and cobalt and nickel isolated by means of two ammonia and three basic acetate separations and then precipitated electrolytically.

While the extremely small amount used for analysis makes the chances of error larger than is desirable, it is believed that fairly accurate results were attained.

The analysis gave:

$\mathrm{Fe}$

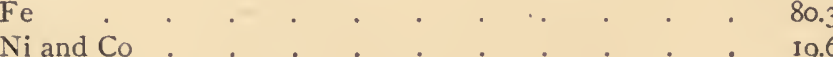

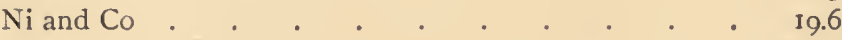


May, igo2. Meteorite Studif, I-Farrington.

This corresponds nearly to the formula $\mathrm{Fe}_{13} \mathrm{Ni}_{3}$, the percentages for such a compound being:

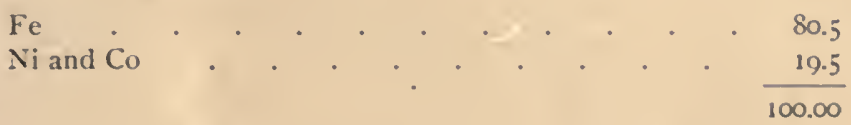

Other analysts have obtained for the percentages of iron in taenite from other meteorites, values ranging from $86.44 \%$ to $57.18 \%$, and corresponding to formulas varying from $\mathrm{Fe}_{6} \mathrm{Ni}$ to $\mathrm{Fe}_{4} \mathrm{Ni}_{3}$. Judging from our present knowledge of alloys it is hardly to be expected that taenite should have a uniform composition. Kamacite, being the substance with the lowest freezing point, is to be considered the eutectic of the series and as such has a fairly uniform composition, but this would not be expected of the other alloy or alloys. 



\section{INDEX.}

Acoustic phenomena of falling meteorites............9, II, It

Aërolites................... 18

Analyses............... 25

Classes................ 24

Definition.............. 18

Description.............. 23

Aërosiderites .............. 18

Analyses............... 19

Definition................ 18

Description .......... 18, 22

Aërosiderolites............... 18

Analyses............... 23

Definition................ 22

Description............. 18

Agates, Theory of formation of... 197

Age of the "Pillar of the Constitution"

Allen, J. A., quoted............ 200

Almy, John D., Communications with...................221

Altitude of Ixtaccihuatl, various determinations of ........ 107

snow line on Popocatepetl... 92

Popocatepetl, Various determinations of ........... 87

Altitudes near the Ranch of Tlamacas.................. go

Aınaga, Iron mining I)istrict of 131,143

Town of ............... 143

Amalfi, Mining District of ...131, 137

City of............... 137

Ameca, Town of ..........78, 308

Ameca-Ameca, same as Ameca.

Amphoterite............... 24

Amyzon shales.............. 199

Anaime, Mercury ores of....... 169

Analysis of-dolomite.........230

Hopewell Mounds meteorite. 313

inesite................ 223

Long Island meteorite...... 297
Page

Analysis of-tænite.......... 314

Toluca meteorite ........ 308

Analyses of meteorites, quoted $19,23,25,310,313$

Anchitherium.............. 185

Andesite, Amphibole, of 1xtacci-

huatl.................. 110

Hyperstliene, of Popocatepetl 100

Anori, History of ........... 138

Mining District of .....131, 138

Antioquia, 1)epartment of ...... 130

District of, West.......... 141

Mining districts and ores of.. 130

Anza, Mining District of. $131,141,142$

A ragonite.............249, 254

Arsenopyrite, in needle form.... 147

Ascent of-Ixtaccihuatl......104, 105

Popocatepetl............ 82

Asiderites...............18, 23

Astruccenia conica........... 215

Awaruite.................. 19

Atlantosaurus................281

Baker, Frank C., quoted..86, 105, 111

Ball, S. H................... I 8 I

Bats, Distribution of in caves.... 148

Becker, G. F., quoted.......... 265

Bibliograplyy-of Geology of Culombia................. 17t

of Popocatepetl and Ixtacci-

huatl ................ 73

Biela's Comet............29, 30

Bird Remains ............. 199

Anatida............... 198

Fringillidx............ 200

Gall:x................. 200

Blatchley, W. S., quoted.247, 249,

$253,264,265$

Bradbury, 1)r. S. M., Correspon-

dence with ..............267

Breccia from weathering of jyr-

rhotite............... It2 
Brongniardite, Occurrence in $\mathrm{Co}$ -

lombia of...........156, 157

Brontosaurus .............. 276

Bronzite - of Long Island meteo-

rite ................293, 299

Ness County meteorite..... 301 Bryan, Wm. A., quoted......... 198 Bustite.................... 24 Calcite, Crystal forms of....... 232 crystals, Coan's Cave....... 265 Joplin.......... 232 " Differentiation of surface planes of..... 236 crystals, Joplin,etching figures 237 " Forms of large

crystals ............. 233 crystals, Joplin, Forms of smaller crystals........ 237 crystals, Joplin, Forms of twinned crystals......... 238 crystals, Joplin, Localities of

large crystals.......... 232 crystals, Joplin, Type I...232, 233

$$
\begin{aligned}
& \text { " " } 11 . .233 \text {, } \\
& \text { 234, } 235 \\
& \text { " " " } \\
& \text { " " " } \quad \text { " IV ... } 238
\end{aligned}
$$

deposited in quiet and mov-

ing waters............. 266

Golden............... 229

twins, Joplin............ 238

" Guanajuato......... 240

in stalactites.........249, 250

Camarosaurus.............. 280

Catalogue of the Meteorite Cellection .................. I

Caledonite.................. 224

Blowpipe reactions of....... 225

Crystal forms of.......... 225

Occurrence of ..........224

Capillary attraction, Influence of on forms of stalactites........25I

Caramantá, Mining District of. I32, I 5 I Carbonaceous meteorites......17, 27

Castillo, Antonio, quoted ....... 308 Cauca, Mines of.....127, 153, 155, 157 Cave Hill Cemetery, Marengo Cave .................... 257 Caves, Observations on Indiana. 247
Page

Cenotes ...................248

Cephalopoda, Development of... 209 Chaicedony................ 195

Chassignite................ 24

Cluna Kiver, Mining District of.. 165

Chladnite ................. 24

Chondri ................... 26

in Long Island meteorite.... 294

in Ness County ". .... 301

Chondritic Structure .......... 26

Chromite-in Long Island meteorite. .293, 294, 295, 297, 299, 300 in Ness County meteorite.... 302 Chrysolite, Absence of.......... 313 of Long Island meteorite.293, 298 of Ness County " ... 30

Circular Halls in Wyandotte Cave. 247

Form of ............. 247

Origin of $\ldots \ldots \ldots \ldots \ldots 247,248$

Structure of............. 248

Classes of Meteorites........... 18

Cleavage in Meteorites........ 22

Coal in Colombia........129, I43, 148

Coan's Cave ................. 264

Bats in ................. 249

Entrance to............. 264

Pool in................ 265

Collection of Ores from Colombia 125

Collections of Ores, Character of ideal .................... 126

Collet, -., quoted.........253, 254

Colorado, Grand River Valley of. 267

Colorado ore, defined......... I 32

Colombia,

General Geology.......... 128

Gold production .......... I25

Mines of ............... I2I

Ores of .............. 121

Pliysical feàtures of........ 128 state of geological science in. 125

Como Beds....267, 271, 276, 279

Compounds in meteorites....... I7

Contributions to the Palæontology

of the Upper Cretaceous Series 205

Cope, E. 1)., quoted..181, 183, 185 , - 200,281

Copper Ores in Colombia....141, 169 Crater of Popocatepetl..94, 95, 96, 97

Dimensions of........... 96 
Crystal Cave, Joplin, Mo....... 234

Crystal forms of

calcite.............229, 232

caledonite............. 225

epsomite.............. 228

gay-lussite.............. 227

inesite................ 221

Crystalline structure of meteorites

$19,21,293,295,301$

Crystals, experiments on growth of ....................... 265

Crystals from quiet and moving water, Characters of ......... 266

Crust of Meteorites........... I

Long Island Meteorite...... 289

Ness County Meteorite..... 300

Dakota group of the Grand River

V'alley .................. 270

Davison, J. M., quoted......... 20

"Diamond Dome," Marengo

Cave.................... 259

Dinosaur Beds of the Grand River

Valley .................. 267

Diogenite ................ 24

1)istribution of - Bats in caves 248,249

Meteorites............. 12

Sciuromorph rodents....... 187

Dolomite, California.......... 23 I

used as Indian money..... 230

Dome-shaped Halls in Caves.247, 253

Form of .............. 247

Origin of ............. 247

Structure of.............. $2 \nmid 8$

1)orsey, G. A., On Mines in Co-

lombia ................ 127

quoted..............230, 310

1)unite ................. 24

1)ust spouts in Mexicu......... 87

Echandia, Mining District of..... 153

Effects of heat on meteorites .... 16

Egg, Fossil................ 193

Measurement of modern.... 199

Elements in meteorites......... 16

Elliott, D. G., yusted........... 260

Eysumite................ 228

Eroded stalactites in Shiloh Cave 262

Erosion in Marengo Cave...... 256

Erosive and solvent action of

water in caves............ 248
Etching figures on Calcite...236, 237 of Meteorites ....20, 21, 306, 31 I

Eucastor ................ $18_{4}$

Eutectic of meteorites........ 315

Farrington, O. C., author.

Crystal forms of Calcite.... 232

Fossil Egg from South Dak.. 193

Handbook and Catalogue of the Meteorite Collection... I

Meteorite Studies, I....... $28_{3}$

New Mineral Occurrences... 221

Observations on Indiana Caves.............. 247

Observations on Popocatepetl and Ixtaccihuatl.

Fasciolaria................ 214

Felix and Lenk, on Ixtaccihuatl.. 104

on Popocatepetl......... 83

Fissure systems, Wyandotte Cave 248

Fletcher, L., quoted.........3, 309

Flus Ferri, Origin of.......... 249

Foute, H. W., quoted ......... 251

Fore Leg and Pectoral Girdle of

Morosaurus............... 275

“Fortress Monroe," Marengo Cave 257

Fossil Birds ............... 199

Anatidæ................ 198

Fringillida............. 200

Gallæ................. 200

Fussil Egg................. 193

Origin.............. 197

Resemblance to those of Ana-

tine Birds............. 198

Fossils of the Grand River Valley 272

Upper Cretaceous Series.... 205

Fossil wood, Organic Matter in... 195

Franklinville meteorite..302, 303, 304

Frias Mine of Guayabal........ 163

Mining I)istrict of......... 163

Frsntino, Mining District of..131, 141

Fusus .................. 215

Gamba,-\$. Pereira, on Colombian

Ores....................125

Gay-Lussite .............., 226

Crystal Forms of.......... 227

General conclusions upon the

mines and geulogy of Colombia. 174

Gunnison River............. 268

Heddle, H. Forster, quoted...... 197 
- Page

"Helen's Dome," Wyandotte Cave 247 Heilprin, Angelo, quoted. .80, 106, I I

Account of ascent by....... 105

Heilprin leak............. II 2

Hess, W W. H., quoted.......... 249

Holmes, IV. H., quoted......... 248

Hovey, H. C., quoted.......... 254

Hyatt, Alpheus, quoted ........ 209

Hystrix refossa............. I 83

Ibague, City of ............. I67

Mining District of......... 167

Iddings, J. P., loan of crystals by . 232

Index to meteorites mentioned in

Museum Handbook and Cata-

logue ................. 62

Indiana Caves, Observations on.. 247

Indian Money.............. 230

Inesite. ................ 22 I

Analysis of ........... 222

Blowpipe reactions of......221

Forms of ............ 22I

Formula of ............. 224

Localities of ........... 221

Iron Ores, in Colombia........ 143

Ixtacciluatl, Observations on.... 67

Glacier on.............. III

Jaguas, defined ............ 147

Jamesonite.............. I 48 , I50

Jerome meteorite.......302, 303, 304

Joint planes in Long Island me-

teorite................. 286

Joplin, Mo., Calcite from.... . . . 232

Jurassic Strata of the Grand River

Valley .................. 260

Kamacite, Composition of ...... 17

in Hopewell Mounds neteor-

ite.................. 3 1

"Kenton County nieteorite. 3I 4

"Toluca meteorite....... 306

Nature of.............. 20

Kansada meteorite.....302, 303, 304

Kenton County meteorite, Analy-

sis of taenite from .......... 314

Kermesite.............. I52

Knight, Prof. IV. C., Communica-

tions from............227, 228

Kunz, Geo. F., Meteorites pur-

cliased from...........8, 34

quoted................. 285
I Page

La Plata del Libano, Mines of, .. I65

L.eaf Stalactites.............. 262

Libano, Mining Districts of ..... 165

Limit of Vegetation on Popocatepetl.................. o2

Loaiza Hill, Silver Mines of..... 153

Logan, Wm. N., autloor, Contributions to the Palaontology of the

Upper Cretaceous Series..... 205

Long Island meteorite,

Analysis of ............. 297

Catalogue of ........... 50

Description of .......... 285

Occurrence of........... 283

Los Reyes, Find of meteorite in. . 305

Location of ............. 308

Ludwig and Soret, puoted....... 265

Magdalena River, Geology of .... I 59

Mammotli Cave, Rotunda in .... 247

Manizales, City of ........... 156

Mining District of......... 156

Map of -Antioquia and Tolima.. 177

meteorite falls in Nortlıwest-

ern Kansas............. 304

Popocatepetl and Ixtacciluuatl I20

Marengo Cave.............. 256

Abundance of stalagmites in 257

Floor terrace in ......... 256

Origin of peculiar stalagmites in............. 257

Rate of growth of stalagmites in ..................26

Stalagmo-Stalagmites in.... 259

Stream deposit in........ 257

Maricuita, Ancient City of....... I 159

Marmato, Mining District....... I 53

Marsh, O. C., quoted.......... 275

Matthews, E. O., Meteorite obtained from .............. 305

Measurements of eggs........ I99

Morosaurus bones......278, 279

Medellin, City of ............. 1 to

Meck, F. IV., yuoted...........2 II

Meniscomys hippodus......... 183

Menke, H. W., Photographs by J9I, 267

Mercury ores in Colombia...... 169

"Mermaid," Marengo Cave..... 259 Merrill, G. P., quoted....249, 251, 254 
Page

Mesugaulus..........184, 185, 186 ballensis.............. 18I monudun .............. 18i sesquipedalis ........... 181

Meteorites, Handbouk and Catalogue of............. I Studies of .............. 283 Meunier, S., yuoted.....288, 295. 303 Milne, Sir Alexander, quoted.... 255 "Milroy"s Temple," Vyandottc Cave.

Mulecular arrangement of stalagmites and stalactites ........ 260

Molino urc. ................ 154

Money, Indian. . . . . . . . . . 230

"Monument Mountain," IY Yyndiste Cave ................ 248 Moraine of Porfirio 1)iaz Glacier. 115 Mornsaurus agilis............. 275 Fore L.eg and P'ectoral Girdle of ................ 275 grandis.......275,276, 278, 279 impar................ 275 lentus ................. 275 robustus ............275, 280

Morton, Nye F., on the ures of Antioxulat................ 130 "Mount Vesurius," Marengo Cave 259 Mylagaulidax............... $18_{1}$ Plyylugeny of............ $18_{4}$ Mylaugaulus ............. 181 Xess County Meteorites....... 300 New Mineral Occurrences....... 221 Nicliuls, H. W.. Analyses by. . 296, 307 3I3. $3 \mathrm{I}+$

Author, Ores of Colombia... 121 Collections by.......... 232 Experiments by........... 265

Nitrates in carc eartlıs........ 249 Oakley meteorite.........303, 304 Observations on Indiana Cares.. 247 P'upucatepetl and Ixtacciliuatl 67 "Odd Fcllow's Hall," Wyandotte Cave................. 247

Ores of Culumbial........... 121

Organic matter in fossils ....... 195 Origin of -stalagmites in Marengo

Cave............... 257 ores in tuff ............ 149
Page

Osborn, H. F., quoted.......276, 28 I

Ostrea .................. 213

Distribution of .......... 213

beloiti................ 214

Packard, A. S., yuoted....77, 86, 103

Palache, Chas., Communication

from .................. 239

Pamplona, City of ........... 170

Mines of ............... 170

Peale, A. S., on the Jurassic of the

Gunnison $V$ alley.........267, 270

Pectoral girdle of Morosaurus... 275

Petrified wond, Organic matter

in ................... 195

Petrigraphy of - Ixtaccilıuatl.... IIn

I.ong Island meteorite. . . . 203

Ness County meteorite..... 30t

Popocatepetl ............. . I00

Phylogeny of the Mylagaulidae.. I 84

Physical features of Colomhia... I 128

Pico del Frailc.............94, 99

"Pillar of the Constitution"..... 252

Age of................. 254

Pirsson, L. V., quoted.......... 240

Pits on meteorites.... 13, 289, 300, 306

Po (Indian money) ........... 231

Popucatepetl, Ascents of......79, 82

$8_{3}, 84,85,86$

Description of.......... 80

Observations on .......... 67

Porfirio Diaz Glacier........... I11

Collecting ground of ....... 112

Fvidences of former extent

of. ................... 115

Middle ground of ......... 113

Terminal portion of........ 114 moraine of $\ldots \ldots \ldots$ I15

Prairic 1)og Creck meteorite..303, 304

Preston, H. L., quoted. . . . . . . . 302

Prestwicl, J., quoted.......... 256

Prionotropis woolgari......... 211

"Prisun Cell," Marengo Cave.... 257

Protogaulus lippodus......... 183

Pseudoperna wilsoni.......... 215

Pyrargyrite..... 156, 158, 160, 164, 166 Quiuna, Gold mine of......... 112

Randolph, Jolun C., on Colombia

159, 164

Reclus, Elisée, quoted...143, 160, 173 
Remedios, City of.......... I 32

Mining District of ......131, 132

Restrepo, Vicente, quoted....144, 162 Riggs, E. S., author, Dinosaur

Beds of the Grand River

Valley of Colorado.......267

Fore Leg and Pectoral Girdle

of Morosaurus .......... 275

The Mylagaulidx......... I $8 \mathrm{I}$

Robertson's Cave............258

"Rock of Gibraltar," Marengo

Cave................... 257

Rodents, Distribution of Sciuro-

morph ................. I87

Rothrock, H. A...........253, 254

"Rothrock's Cathedral," Wyan:

dotte Cave ............... 247

"Rotunda," Mammoth Cave. ... 247

"Sand Pit," Marengo Cave...... 257

San Pedro Mining District... 131, I 40

San Sebastian de la Plata....... I59

Santa Ana Mine, History of ...... 162

Santana, Mining District of...... 163

Santa Rosa de Osos, City of...... 139

Mining District of......131, I39

Scaphites. ............... 207

Distribution of .......... 207

nodosus ............... 209

cequalis................. 207

Ontogeny ............. 208

Paleontogeny........... 208

Phylogeny.............. 208

ventricosus ............. 2I I

warreni .............. 209

" revised and enlarged

description of .......... 210

Scheidery, defined............ I96

Schlemm, W.H. ............22I

Schreibersite .......17, 19, 22, 307

Sciuromorph Rodents, Distribu-

tion of ................... 187

Scott, W. B., quoted.......... $18 \mathbf{1}$

"Senate Chamber," Marengo

Cave............247, 248, 252

Senft, F., quoted.....249, 250, 254, 257

Shilol Cave................ 262

Eroded stalactites in ....... 262

Leaf stalactites in......... 262

Stalagmo-stalagmite from... 259
Page

Sierra de Ahualco.........73, 75

Route to the Mountains of... 77

Former fauna of ......... 76

glaciation of ....... 77

Time of origin of.......... 76

Lavas of............76, 77

Sigmogomphius ........... $18+$

Slickensides,

in Long Island meteorité.... 288

in meteorites ............ 27

Origin of ............ 288

Snow Line, altitude of on Popo-

catepetl ................ 92

Soledad, Mining I)istrict of...... I6I Specific gravity,

of fossil egg............ ro

of inesite ..............223

of Long Island meteorite.... 292

of meteorites in general.. 19 ,

$23,26,39$

of Ness County meteorite.... 301

Stalactites, Eroded .......... 262

Leaf.................. 262

Molecular arrangement of... 260

Modified by capillary action. 25I

Vermiform ............. 249

Stagmalites, Definition of....... 261

Rate of growth of........ 26 I

Stalagmites, Abundance of in

Marengo Cave......... 257

Bermuda............... 255

Origin of .............. 258

Molecular arrangement of... 260

from Robertson's Cave..... 258

Variations in the form of ... 258

Stalagmo-stalactites.......... 259

Steplanite in Colombia........ 156

Stibnite in Colombia $151,152,158,161$

Stratigraphy of the Grand River

Valley ................ 268

Stream deposit in. Marengo Cave 257

Subcarboniferous strata in Tolima 129

Subcarboniferous limestone from

Santander.............. I29

Sucre, Mining District of....... 16 $\mathbf{I}$

Sulpluur Mines on Popocatepetl 89, 90

Supia, Mining District of ....... 155

Syenite, Usc of the term in Colom-

bial................... I33 
Taenite, Analysis of from Kenton

County meteorite ....... 314

Composition of $\ldots \ldots \ldots .17,315$

Description of ......20,307, 312

Tellurides of gold in Colombia .. I41

Terminal Moraine, Porfirio Diaz

Glacier................ 115

Terrace on cave foor ......... 256

Thames, Rate of erosion by ... . 256

Thumbmarks of meteorites..... I4

Titiribi, City of ............. I44

Mining District of .....132, 144

Origin of ores of .......... 149

Tolima, Department of ........ I59

Mining Districts and ores of. 159

Volcano of ............... 160

Toluca meteorites, Analyses of, quoted ............... 3 ro

Distribution of........... 308

Triassic strata of the Grand River

Valley ................. 268

Troilite........17, 22, 291, 302, 307

Turner Mounds meteorite, Analy-

ses of, quoted............. 313

Uncompahgre Plateau ........ 267

Upper Cretaceous Series, Palæ-

ontology of ...............205

Venadillo, Mining District of.... 167

Vermiform stalactites......... 130

Vetas de cajon...........130, I39

Viviparus.................. 272

Volcano of Popocatepetl........ 80
Page

Volcano of Tolima........... 160

Ward's Natural Science Establishment, Meteorites obtained from ..................8, 34

Ward, Henry L., quoted....... 302

IV ashington, H: L., Loan of section by .................... 304 quoted ................ 303

"Washington's Monument," Marengo Cave .............. 258

Weinschenk, E., quoted.....292, 304

Weller, Stuart ............. 209

Wellmanville meteorite..303, 304, 305

Western Antioquia Mining Districts................. I3I, I4I

Widmanstätten figures, Dẹscription of .............20, 2 I of Hopewell Mounds meteorite ................ 3I I of Toluca meteorite....... 306

Weyman, Henry, on Crystal Cave. 234

White, Robert, on petrography of

Colombia................ 129

Willard, J. T., quoted........... 283

Williston, S. W., quoted.....267, 283

Wyandotte Cave, Circular halls in 247

Distribution of bats in ...... 248

Fissure systems of ........ 248

"Pillar of the Constitution" in 252

Vermiform stalactites in.... 249

Zancudo Establishment...... I44, I45 

UNIVERSTTY OF ILLINOIS-URBANA

||||||||||||||||||||||||||||||||||||||||||||||||||||||||||||||||||||||| 30112061063910 